\title{
تأديب الاطباء العاملين في الإدارة الصحية العامة في التشريع العراتي
}

م. د. وليد مرزه المخزومي: كلية القانوز - جامعة بـغداد.

م. د. وفاء عبد الفتناة عواد: وزارة التعليم العالي والبحث العلهي.

الاقدهمة

غنيُ عن البيان أن التأديب يُعد أحد الضـرورات التي تقوم عليها كافة المجتمعات المنظمـة, حيث أن كُل مجموعـة اجتماعيـة تقوم على أسس يجب أن تحسفظ عليها وتحميهـا لتحقيق أهدافها ورسـالتها وبخـلاف ذلك تتعرض للمساءلة, والاطباء هم بشر يجري عليهم ما يجري على سائر البشر فيهم من يصيب وفيهم من يُخطئ لذا أقر التشريع العر اقي والمقارن بصدد ممارسة مهنة الطب آلية مسـاءلة الاطباء انضباطيا عن أعمالهم التي تُشكل إخلالاً بوظيفتهم الطبية وفق قو اعد واجر اءات خاصة سيما وأنهم يقومون برسالة سامية .

تبرز أهميـة البحث في هذا الوقت لأنتا في عصر امتلأت فيه المجتمعات بالاخطاء الطبيـة التي اخذت تضرب صحة الانسان وتهدد حياته وحياة افراد عائلته ,و إذا كان التأديب يمثل بصفة عامـة ضرورة لكل حياة اجتماعية منظمة , فأن الهدف من تأديب الاطبـاء هو كفالة حسن سير مرفق الصحة العامـة من خـلال تقويم

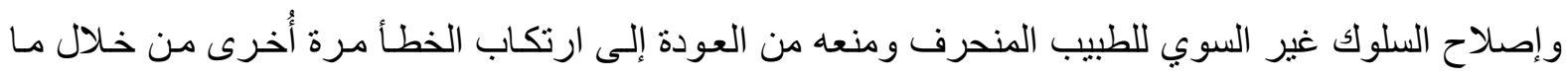
يوقع عليه من جزاءات ناديبية, و لا يتحقق مغزى البحث إلا أن تتم المو ازنـة بين هدفين يكادا يكونـا متعارضين

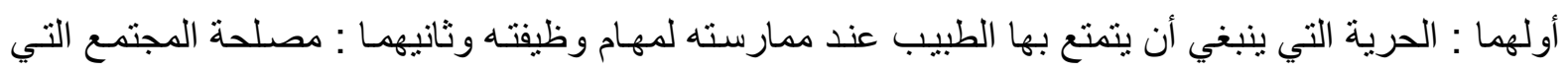
تقتضي إصلاح الضرر الذي لحق بالمضرور و الناجم عن العمل الغير مشروع للطبيب لكن محاولة التوفيق

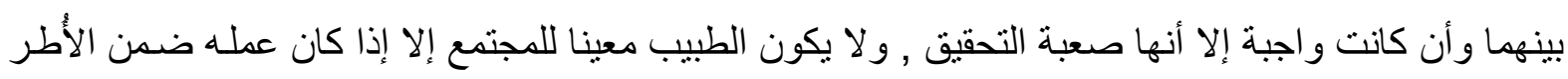

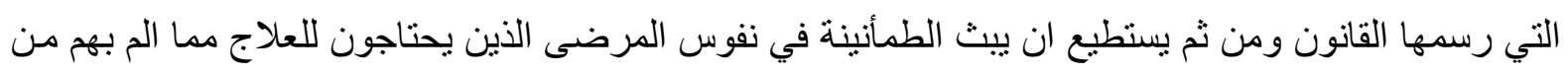
امر اض ـ وفي هذا البحث سنعرض لاركان المسؤولية التأديبية للاطباء في الإدارة الصحية العامـة وذلك في مطلب أول ثم نعرج للبحث في آتار تلك المسؤولية وذلك في مطلب ثانِ ـ وكما يأتي :

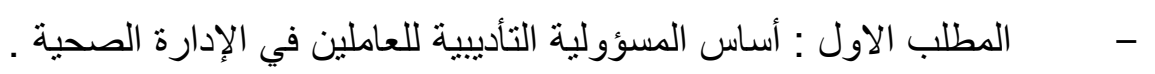
المطلب الثاني : آثار المسؤولية التأديبية للعاملين في الإدارة الصحية .

\section{الاطلب الأول- أركان المسؤولية التأديبية للعاملين في الإدارة الصمية}

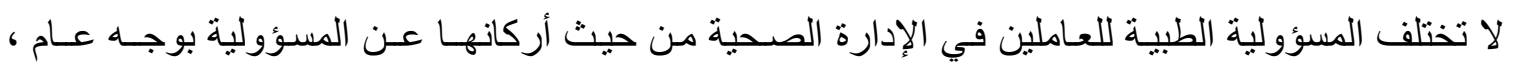

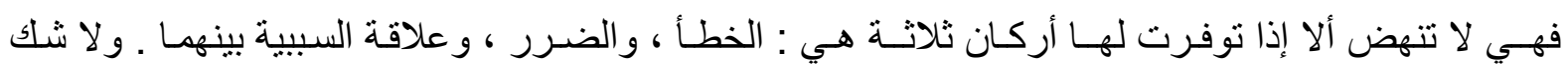

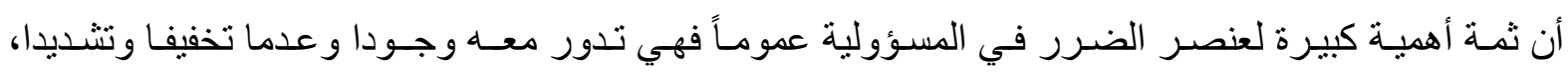

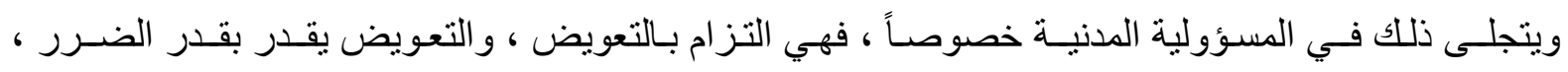

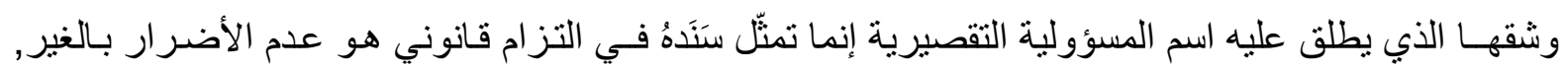
وقد لحقت المسؤولية التقصيرية العديد من التطورات التي ترجمت اهتمامـا متز ايدا بعنصر الضـرر واستبعاداً 
لعنصـر الخطـأ وقد تجسدت هـذه التطورات في أفكار شتى ، منهـا إقامـة المسؤولية على خطـأ مفترض قابل

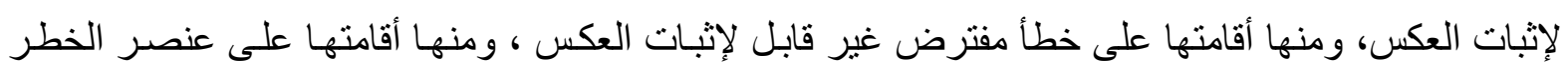

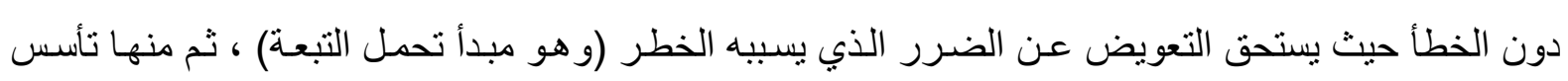

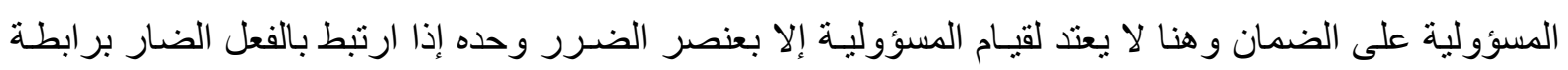

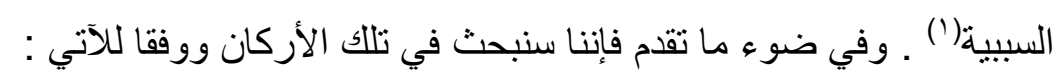

\section{الفرع الأول: الخطأ الشخصي للهاملين في الإدارة الصحية :}

مما لاشك فيه أن العاملين في الإدارة الصحية هم ليسوا الأطباء فحسب و إنما زيادة على هؤلاء الأطباء

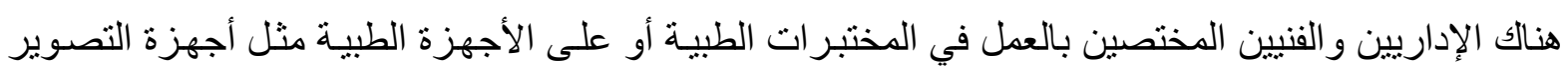
بالأشعة والصيادلة وغير هم من الموظفين في الإدارة الصحية , هؤلاء جميعا يمارسون أعمال متنوعة ومختلفة

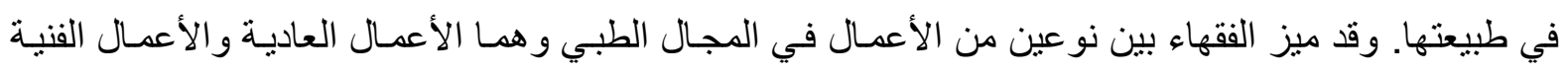
وبالتالي فأن الأخطاء التي تنشأ عن هذه الأعمال تختلف في طبيعتها , ففي النوع الأول هي أخطاء عاديـة وفي الثاني هي أخطاء فنيـة , وقد ثار جدل كبير في الفقه وأحكام القضـاء حول مسؤولية الطبيب بصفة خاصـة وأحوال قيامها(؟) . يمكن تعريف الخطأ الثخصي بأنه ذلك الخطأ الذي ينسب إلى الموظف نفسه , عند وجود تقصير منه يصل الى درجة انه يخالف جميع القو اعد والأصول المهنية وما يمليه عليه ضميره(َّ). ويعـد الخطـأ.

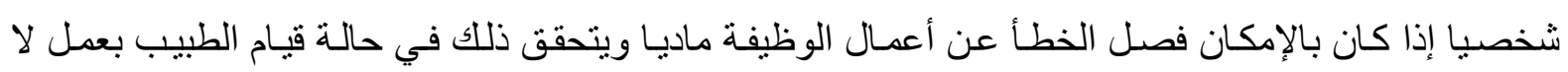
علاقة له ماديا بو اجبات الوظيفة , كأن يقوم الطبيب الذي يعمل في مستشفى عام بإجر اء عمليـة جر احيـة لجيرانه

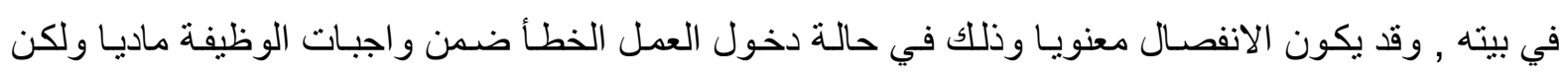

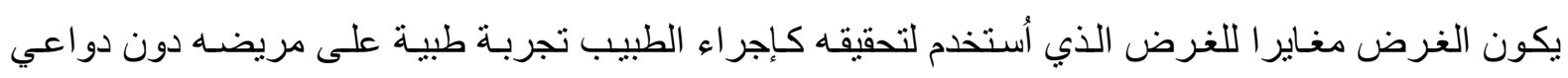

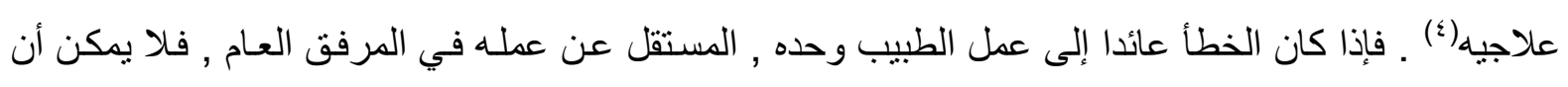
ينسب أي خطأ إلى المستشفى , إلا إذا كان خطأ الطبيب راجعا إلى سوء تأدية المرفق العام لعطله(0) .

هذا وان الر اجح في الفقه أن الطبيب العامل في المستشفى العام يعد تابعا لها حتى لو كانت هذه التبعية

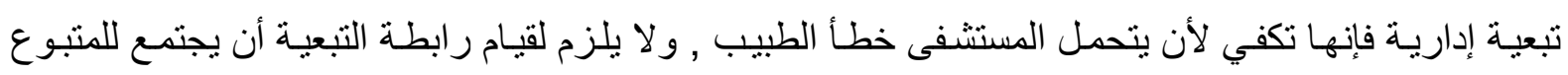

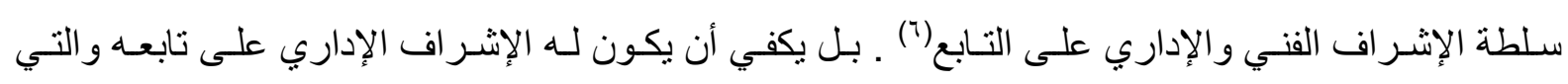

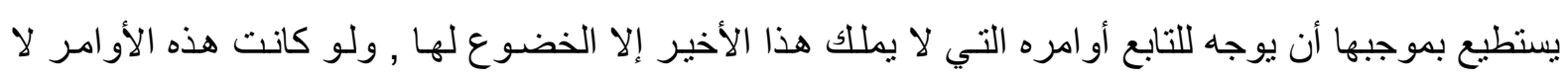

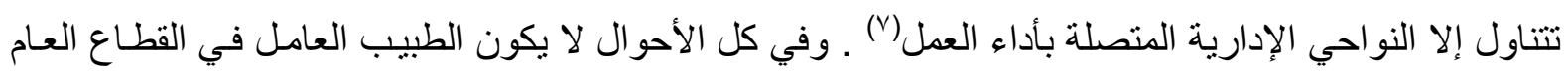

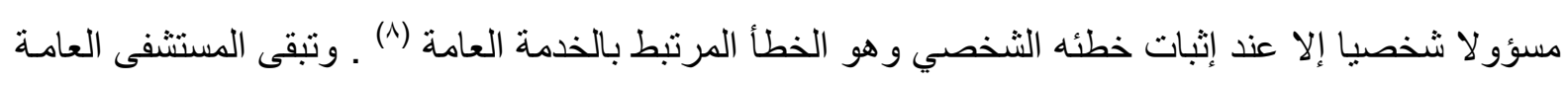
مسؤولة عن أعمال الطبيب ما دام هذا الطبيب يتقاضى أجر ا منها , أما إذا كان الطبيب عـاملا في القسم الخـاص بلاص في المستشفى العام , كعطه في العيادات الخاصة , في هذه الحالة يعد الطبيب عاملا لحسـابه الخاص وبالتالي لا تكون المستشفى مسؤولة عن أخطائه(9) ـ و إن علاقة الطبيب بالمستشفى العام هي علاقة قانونية تنظيميـة ينظمها القانون , إذ إن المستشفى الحكومي مرفق عام و الطبيب موظف في هذه المستشفى وتوصف علاقة الموظف 
بالدولة بأنها علاقة تنظيمية , أي أن الموظف ( الطبيب ) في مركز تنظيمي يخضع لما تضعه الدولـة من قواعد

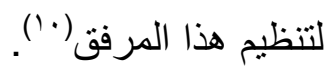

وفي مجال تحديد الخطأ الموجب لمسؤولية الطبيب ظهر اتجاهـان فقهيـان الأول : تزعمه الفقيه الفرنسي

(ديمولوب) الذي فرق بين العمل المادي من ناحيـة و العمل الفني من ناحيـة اخرى , والثاني : فرق بين الخطأ الجسيم والخطأ اليسير , واختلفت اتجاهات الفقه وأحكام القضاء من حيث نوع الخطأ الذي يثير مسؤولية الطبيب عن عمله الفني , إلا أن الفقه و القضـاء سواء في فرنسـا او في مصر قد استقرا على ان الطبيب مسؤول عن الأخطاء التي تقع منه أثناء ممارسة مهنته وكذلك عن الضرر المتسبب عن إهمالـه وعدم احتياطسه في تشخيص الداء ووصف الدواء و إجر اء العمليات و لا يلزم لقيام هذه المسؤولية أن يرتكب الطبيب خطئًا جسيما إذ لا يوجد الأدئ في نصوص القانون ما يعفي الطبيب من المسؤولية عن الخطأ اليسير متى ما كان واضحاء(') , ومن التطبيقات

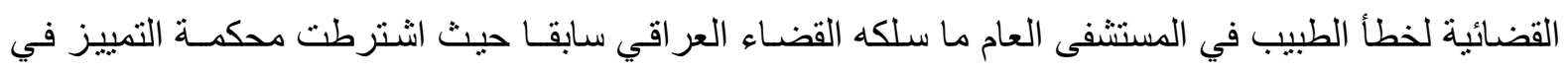
حكم لها ان يكون الخطأ الجسيم شرطاً لمحاسبـة الطبيب اذ قررت قائلـــة ((... ولدى عطف النظر الى الخطأ

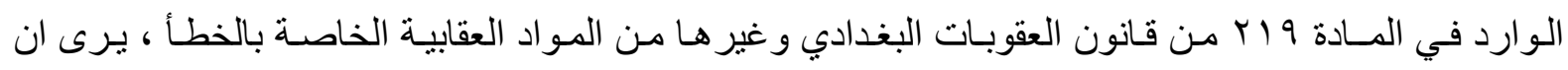
البحث عن الخطأ جاء بنص عام لا يفرق بين الطبيب وغيره , ولكن فريقاً من الثر اح و الفقهاء يقسمون الخطأ

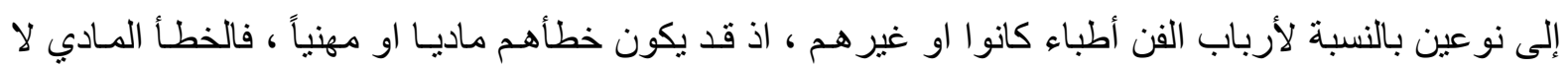
يخضع للمناقثنات و الخلافات الفنيـة ويقسم الفقهاء الخطأ الفني على اثنين احدهما الخطأ اليسبر وثنانيهما الخطأ الجسيم ، فيقرر بعضهم المسؤولية الجنائية في اليسير والجسيم من الأخطاء الفنية ، أمـا البعض الآخر فيحصر المسؤولية الجنائية في الخطأ الجسيم فقط لان الطب علم سريـع التطور يتصـار ع فيه قديمهـ وحديثه صـر اعاً

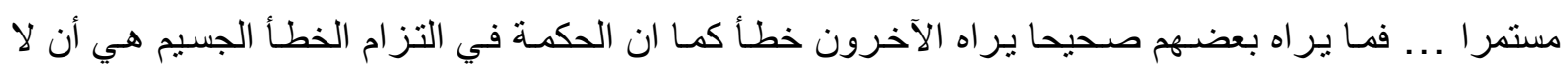

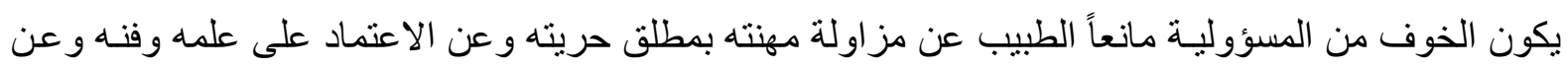

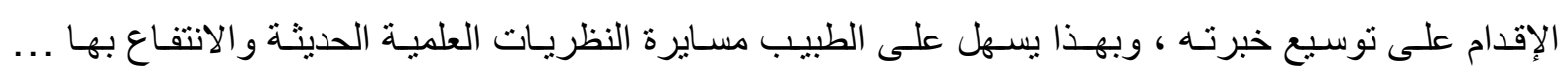

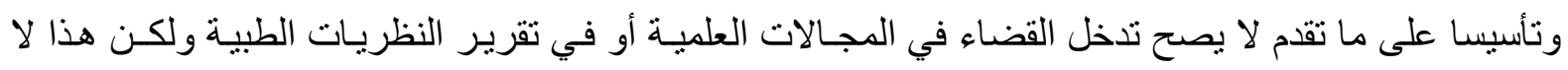
يمنـع الحاكم من استغلال سلطتـه الواسعـة في تقديـر المسؤولية الطبية طبقاً للقواعد المسلم بها فقها وقضــاء لان

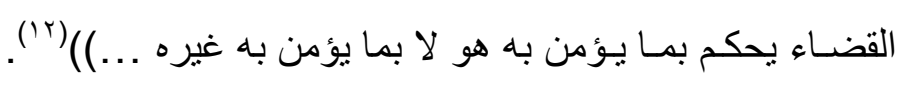
إن الخطأ المهني (أو الفني) يقع فيه الطبيب لدى مخالفته القواعد الفنية التي توجبها عليه مهنته التي يجب

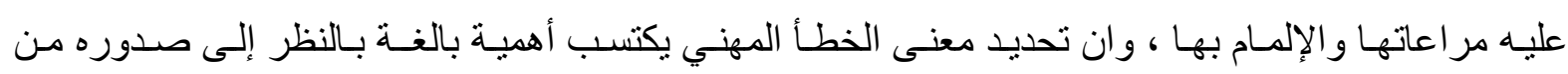
أثخاص متعددين ذوي أعمال منسمة بالخطورة , وذلك من مثنل الطبيب الجـراح أو الطبيب المعالـج أو طبيب التخدير أو طبيب الأشـعة أو غيرهم، الأمر الذي يوجب استجلاءه والإحاطـة بـه بغيـة إنـارة الطريق للقاضـي

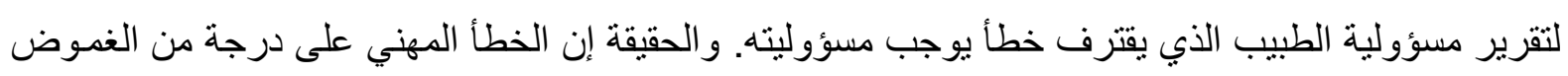

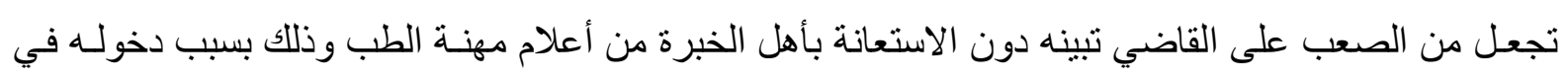
نطاق المهنة التي يزاولها الطبيب ، وعدم تساهـل أهل العلم في الأصـول الثابتـة التي يعرفونها ولا يتسـامحون 
مـع مـن يجهاهـا مـن أهل المهنة أو الفن ، ولذا يلجأ القاضي إلى الخبراء لمعرفة ، مـا إذا ارتكب زميلهم خطأ أم

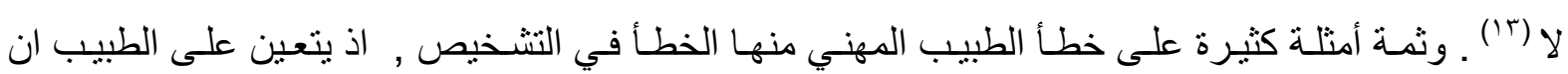
يشخص داء المريض بكل حكمة وتبصر و على أساس مـن العلم و الفن و أصسول المهنـة وليس برعونـة وطيش

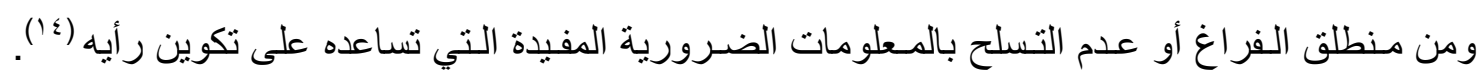

\section{الفرع الثاني : الضرر الناجم عن أخطاء العاهلين في المرافق العاهة الصحية :}

لا يكفي توفر عنصر الخطأ بمفرده لقيام المسؤولية , بل لا بد من توافر عنصر الضرر, الذي ينتج عن هذه

الأخطاء(1). و الضرر هو مساس بحق من حقوق الإنسان أو بمصلحة مشروعة لـه ، والحقوق هذه لا تقتصر

على أضر ار الجسد الماديـة وإنمـا تشكل كل حق يخول صـاحبه سلطة او مز ايـا او منـافع يتمتع بها في حدود

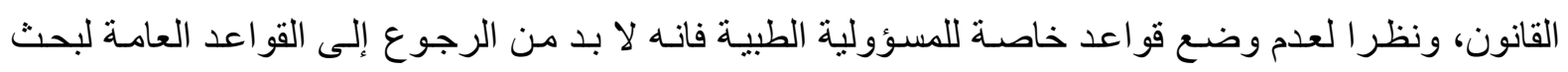

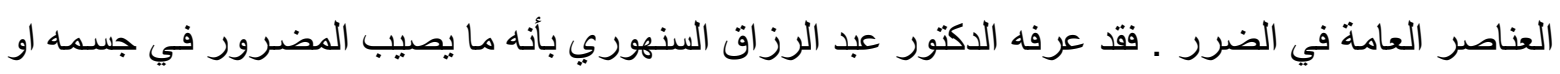

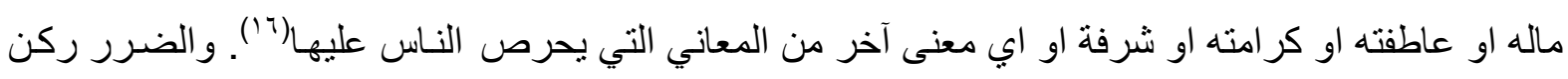
جوهري من أركان المسؤولية المدنية بنوعيها العقدية و التقصيرية ، لا بل هو مناط هذه المسؤولية التي لا تقوم

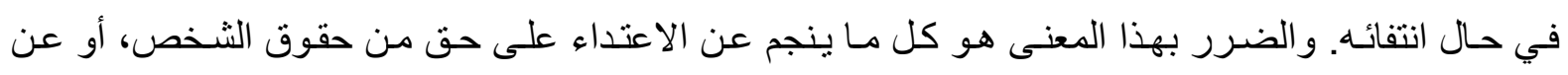
الإخلال بمصلحة مشروعة له، حتى لم يكن القانون يكفلها بدعوى خاصـة. وحتى يكون هنالك إضرار بمصلحة مشروعة يجب أن يثبت المضرور بأنها فقد شيئًا بسبب الفعل الذي ينسبه للفاعل ـ وفي مثنل هذه الحسال يتم المقارنة بين الوضع الحالي للمضرور والوضع الذي كان من الممكن أن يكون موجوداً لو لـ يقع الفعل الضـار.

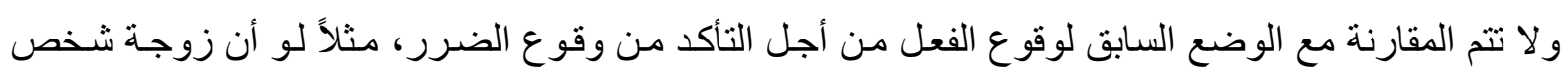
توفي نتيجة إهمال من الطبيب او من أحد الممرضين ، حصلت على عمل بعد وفاة زوجها، وبالتالي فإن هذا العمل منحها وضعاً مالياً مشابهاً أو أفضل من الوضع الذي كان يؤمنه لها زوجها قبل وفاته، فإن ذللك لا يحرمها من حقها في المطالبة بالتعويض بسبب فقدان المسـاهمة التي يقدمها لها زوجها قبل وفاتهـ. ولكن يجب في كل الأحوال أن يترتب على الفعل المنسوب للمسؤول خسارة بالنسبة للمضرور ـ ففي بعض الأحيان ، على الرغم

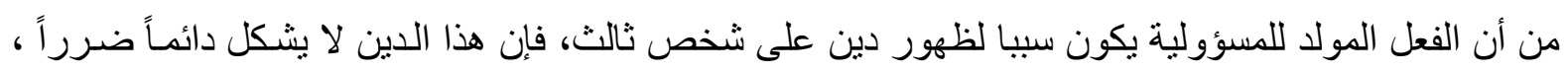

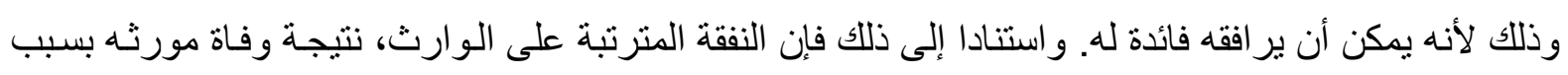
خطأ طبي مثثلا ، والمتمثلة بتسديد ضـريبة التركات لا تشكل ضـرراً ناجمـاً عن الحسادث الذي أدى إلى وفـاه مورثه , وبالتالي لا يحق لله المطالبة بالتعويض عنها, ويشترط في الضرر لكي يجري التعويض عنه ان يكون

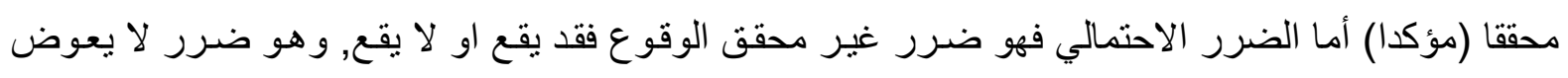
عنه إلا إذا زال منه عنصر الاحتمال بأن وقع فعلا, ومثال ذللك إدعاء امر أة ان زوجها الذي توفي بسبب خطأ الطبيب كان سيحصل على عمل بأجر عالِ مستقبلا فتطالب بـالتعويض عمـا فقده من هذه الأجور بسبب موتـه,

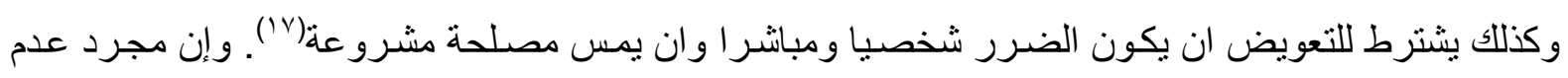

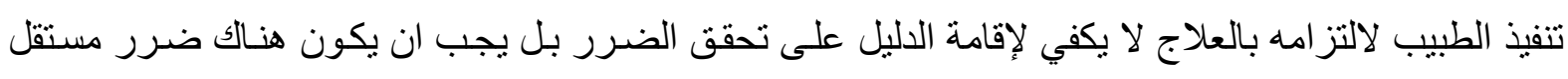

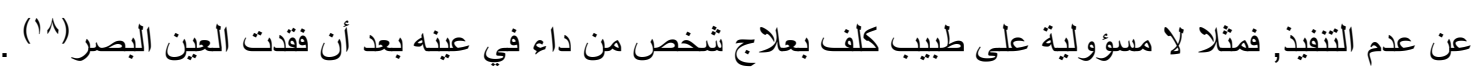


يثكل ركن الر ابطة السببية أساس في المسؤولية المدنية عموما ، لأنه لا يمكن نسبة الضرر إلى الخطأ إذا لم تكن هناك علاقة سببية تجعل الخطأ علـة الضرر وسبب وقوعه . أن جوهر المسؤولية ومناطها هو تلك

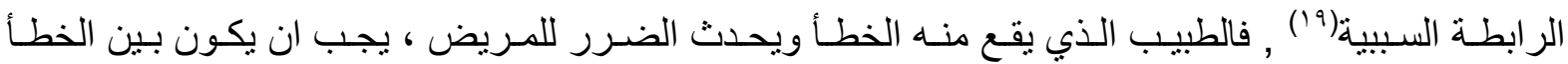
و الضرر علاقة سبيية، وهذه العلاقة شرط ضروري وركن مستقل عن ركن الخطأ ، فقد يقع خطأ من الطبيب و لا يكون هذا الخطأ هو السبب فيما أصـاب المريض من أضرار، كمـا لو أهمل الطبيب بتعقيم آلاته الجر احيـة فمات المريض بسكتة قلبية مفاجئة لا علاقة لها بالخطأ المرتكب من الطبيب(·r) فيشترط ان تكون السببية بين الخطأ والضرر محققة ومباثـرة وتحديد الرابطة السببية في المجال الطبي من الأمور الثـاقة والعسبرة نظرا لتعقيدات العمل الطبي والجسم الإنساني فقد ترجع اسباب الضرر إلى عوامل بعيدة ، او عوامل خفيـة تعود إلى

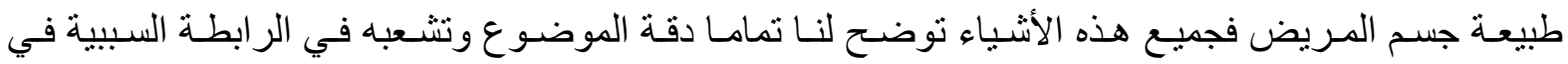
مسؤولية الأطباء ، فاثتنر اك عوامل عدة في إحداث ضرر واحد ، يجعل من الصعب تعيين مـا يعتبر سبب حقيقي لهذا الضرر وما لا يعتبر كذلك ، هذا وتنص المادة (TrY) من القانون المدني الأردني على أن (( يقدر الضمان في جميع الأحو ال بقدر ما لحق المضرور من ضرر ومـا فاتـه من كسب بشرط ان يكون ذلك نتيجة طبيعية للفعل الضار))('). . هذا ويجب على مدعي الضرر إثبات أركان المسؤولية بمـا فيها العلاقة السببية التي يمكن إثباتها بجميع طر ائق الإثبات بما فيها القرائن القضائية ، وفي الواقع يمكن إثباتها عن طريق واقع الحال ، بل كثير ا ما تكون هذه القرائن واضحة ، بحيث إن الأمـر لا يحتاج لدليل لتو افر السبيية ، ويجوز نفي الرابطة السبيية بطريقة غير مباثرة اي ان الضرر الذي لحق بالمريض نتج عن سبب أجنبي آخر سواء كان هذا السبب

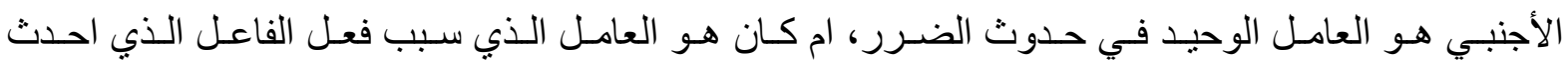
الضرر(rr) ـ و عليه فان صور انعدام السببية وقطعها بتو افر السبب الأجنبي هي ثلاثنة صور ، الحسادث الفجائي او القوة القاهرة ، وخطأ المضرور وخطأ الغير ولإثبات كون السبب الأجنبي هو الذي أدى إلى الضرر يجب هب هب التمبيز بين فرضين ، أولهما :- ان يكون السبب الأجنبي هو السبب الوحيد في وقوع الضرر و الثاني :- ان

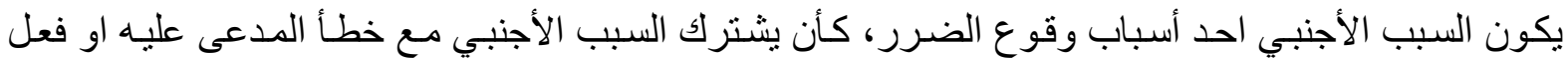
الغير، مع الإشارة انه ليس من الضروري ان يكون فعل الغير خطأ . وهذه الصور هي ما سنبينه فيما يأتي : اولا : الحسادث الفجائي او القوة القـاهرة: ويشترط في الحادث المنتج للضرر لاعتبـاره قوة قاهرة او حسادث فجـائي تـو افر عدة شـروط وأهمها عدم إمكانيـة التوقـع ، فـإذا كـان الطبيـب يتوقع حدوث الضـرر ولـم يتخـذ

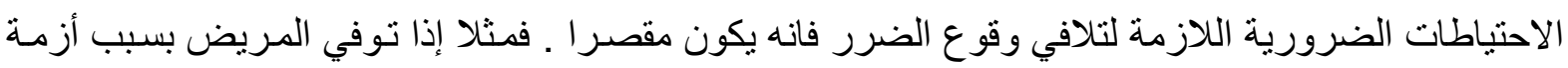
قلبية أثناء المعالجة بسبب حدوث رعد مفاجئ ، فإذا تمكن الطبيب من إثبات ان هذا غير متوقع فيمكن ان يعفي من المسؤولية وكذللك استحالة الدفع ، بمعنى انهه يستحيل على الطبيب دفع الحـادث الذي أدى إلى الضـرر بالمريض ، و الاستحالة هنا هي الاستحالة المطلقة ، سواء كانت مادية او معنويـة ولكن اذا كانت هذه الاستحالة نسبية قاصرة على الطبيب المعالج فلا يعتبر الحادث قوة قاهرة و لا يعفي الطبيب من المسؤولية . 
ثانيا : خطأ المريض : فإذا أثتبت ان الضـرر نـاتج عن تقصير و إهمال الطبيب فانه يسـأل حتى ولو كان هناك

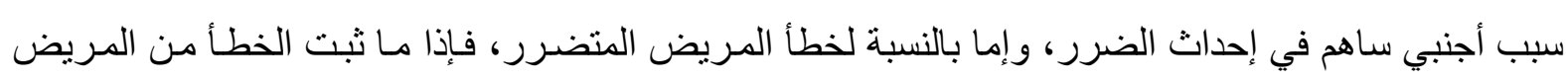
المتضرر فان ذلك يؤدي إلى نفي المسؤولية عن الطبيب وذلك بنفي الرابطة السببية ، شريطة ان يكون خطأ المريض هو السبب الوحيد في إحداث الضرر، أما إذا اشترك فعل المريض مع فعل الطبيب في وقوع الضرر، إنى فان ذللك لا يؤدي إلى انتفاء مسؤولية الطبيب و إنما يؤدي فقط إلى انتقاص التعويض المحكوم بـه على الطبيب ، بنسبة خطأ المريض ، ويأخذ القضاء في هذا الصدد بنظرية السبب المنتج وليس بنظرية تعدد الأسباب التي تقوم بالاعتداد بكافة الأسباب التي أحدثت الضـرر وذلك بخلاف نظريـة السبب المنتج والذي تقوم بالاعتداد بالسبب

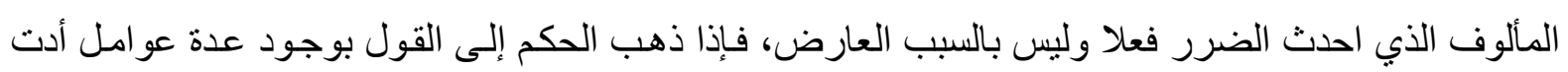
إلى حدوث الضرر للمريض ، دون ان يتحقق الحكم من ان أحد هذه العو امل يشكل السبب المنتج في إحداث

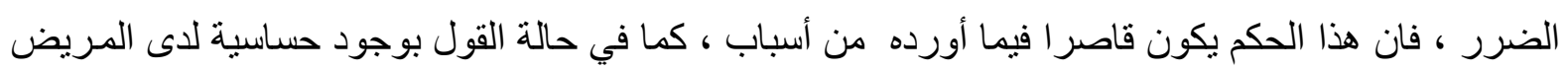

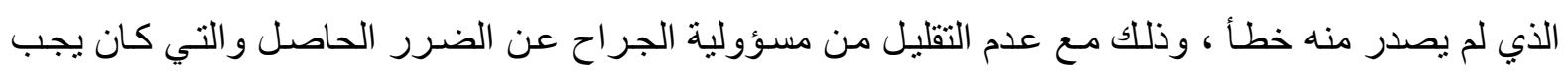

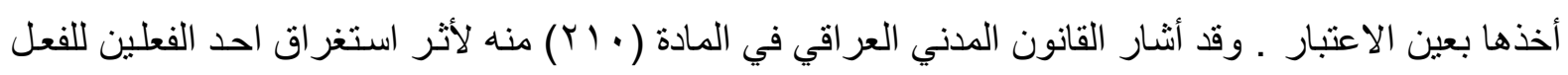
الآخر حيث نصت المادة على انه (يجوز للمحكمة ان تنقص مقدار التعويض او الا تحكم بتعويض مـا اذا كان المتضرر قد اشترك بخطئه في احداث الضرر او زاد فيه او كان قد ساوى مركز المدين)(بَّات. هذا النص يعالج عدة حالات ، منها انه ليس للقاضي إنقاص التعويض ويكون ذلك في حالة استغر اق فعل الطبيب لفعل المريض ، او ان لا يحكم بـالتعويض ، وهذا يفترض ان فعل الطبيب قد استغرقه فعل المريض،

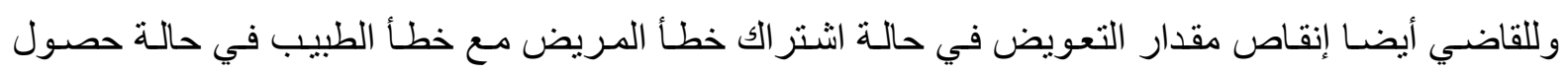
الضرر ـ و هذا ما استقر علية القضاء في مصر، فإذا كان المضرور قد اخطأوساهم بخطئه في إحداث الضرر الذي أصابه فان ذلك يجب ان بر اعى في تقدير التعويض المستحق له فلا يحكم له على الغير الا بالقدر المناسب

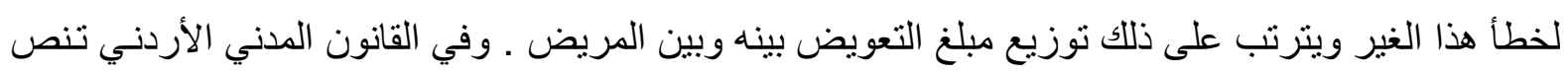

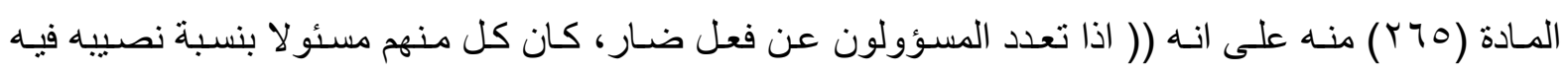

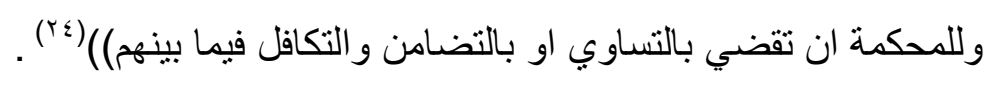

ثالثا : خطأ الغير : فقد تتنفي الرابطة السبيية أيضا نتيجة لخطأ الغير اي ان الضرر قدوقع بفعل الغير، وهو السبب الوحيد في إحداث الضرر، ويجب ان لا يكون الغير من الأشخاص الذين يسأل عنهم الطبيب، سواء كان

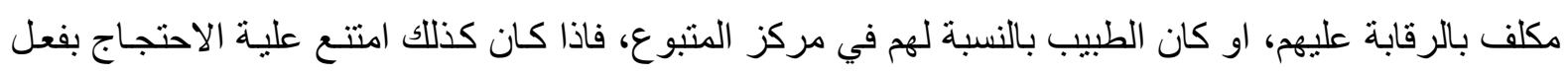

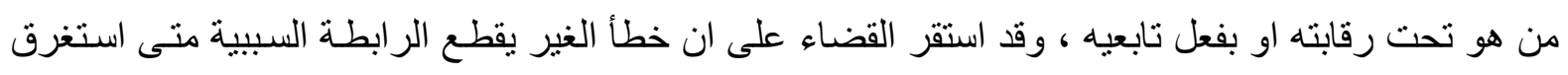
خطأ الطبيب المدعى عليه ، أما إذا كان خطأ الطبيب مستغرق لفعل الغير فلا يعتد بفعل الغير، وتقوم مسؤولية الطبيب كاملـة، فإذا ثبت ان الخطأ صـادر مـن طبيب آخر او مـن أحد العـاملين بالمستشفى او في عدم تتفيذ تعليمات الطبيب , أو إذا مـا ثبت ان الطبيب قد اتخذ الاحتياطـات اللازمـة لمنع وقوع الضـرر بـالمريض ، فـلا تقوم مسؤولية هذا الأخير , وبهذا قضت محكمة النقض المصرية على ان (( خطأ الغير يقطع الرابطة السببية 
متى كان خطأ الغير كافيا بذاته لإحداث الضرر ...)(ro() ـ و على الرغم من ذلك كله فثــة أحوال أخرى تفضـي

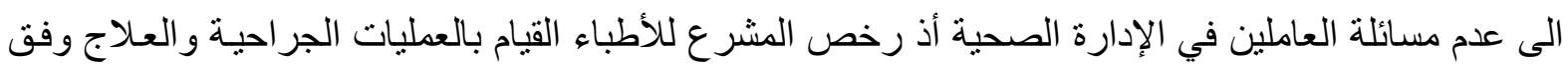

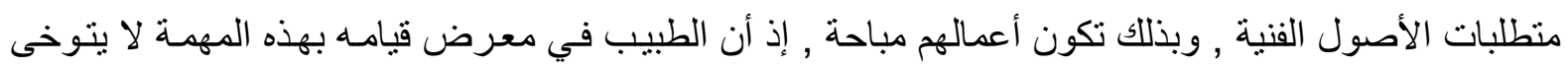
سوى مصلحة إنسانية ولو كان من الجائز أن تترتب على تلك المهمة جروح خطيرة او قطع او خلع أو إتـلاف جزء من أجزاء الجسم , ولربما يؤدي ذللك إلى وفاة المريض , ولكي يكون الفعل مباحا ينبغي ان يكون من يقوم به مرخصا بالقيام بممارسة مهنة الطب وبخلافه يكون مسؤو لا عن النتائج التي يحدثها في جسم المريض

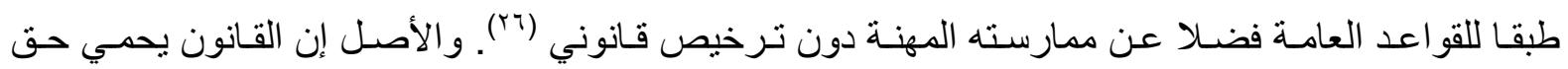
الإنسان في سلامة بدنه , فيعاقب على أفعال الجرح أو الإيذاء او إحداث عاهـة مستديمة , لكن الحق في سـلامة

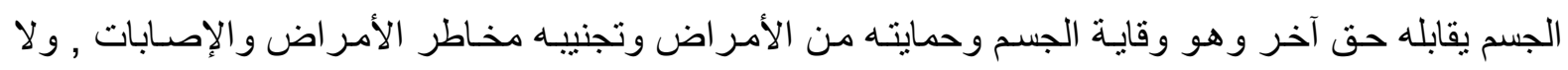
يتيسر تحقيق ذلك إلا بإباحـة أفعـال العـلاج أو الجراحـة ـ وأختلف الر أي حول الأسـاس الذي يقوم عليه حق الطبيب في إجر اء العلاج أو الجراحة , وهي أفعال تمس أبدان الناس وقد ينجم عنها أحيانـا موت إنسان . فهناك رأي يرى أصحابه أن أساس الحق هو انتفاء القصد الجرمي لدى الفاعل ويعلل رأي آخر الأسـاس الذي يقوم عليه برضاء المجني عليـه " المريض " بعمل الطبيب , ويسنده رأي ثالث ـ و هو مـا نميل إليهه ـ إلى القانون كونه هو الذي أباح أفعال الطبيب(rV) ـ ويشترط لتطبيق نص إباحة أعمال الطبيب عدة شروط أهمها أن يكون الفاعل طبيبا وممارسا لمهنة الطب في مجال اختصاصه وفق القانون , وكذلك ان يتو افر رضاء المريض أو من يمثله إلا إذا تعذر ذلك وكانت حالة المريض لا تحتمل ذللك , وأخير ا يجب أن تكون الجراحة أو العلاج على ولى ولى أصول الفن , والمقصود بأصول الفن هو القيام بالعمل الجراحي أو العلاجي وفق الأصول المقررة علميا , فإذا

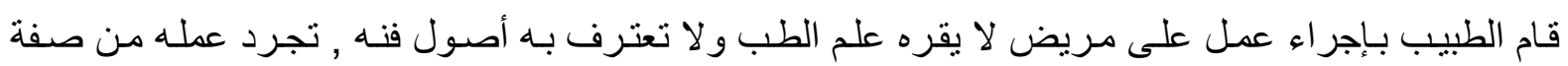

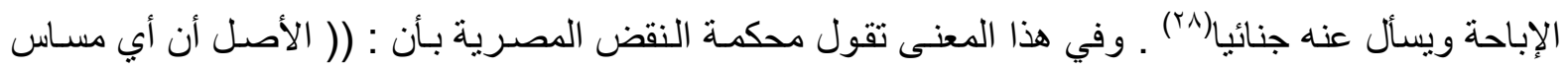
بجسم المجنى عليه يحرمه قانون العقوبات وقانون مزاولة مهنـة الطب , و إنمـا يبيح القانون فعل الطبيب بسبب حصوله على إجـازة علميـة طبقا للقو اعد و اللوائح , هذه الإجـازة هي أسـاس الترخيص الذي تتطلبه ونه القوانين الخاصة بالمهنة الحصول عليه قبل مزاولتها فعلا وينبني على القول بـأن أسـاس عدم مسؤولية الطبيب استعمال الحق المقرر بمقتضى القانون , إن من لا يملك حق مزاولة مهنة الطب يسأل عمل يحدثه للغير من جروح ومـا إليها بإعتبارهـ معتديا ـ أي على أسـاس العمد - و لا يعفى من العقاب إلا عند قيام حالة الضرورة بشروطها (القانونية () (ب9)

أما عن عمليات التجميل فأنه لا شك أنه لا ينظر إليها في الوقت الحاضر كونها مجرد عمليات جر احية بـل أصبحت نتائجها تحقق تحسـا مرموقـا في تجميل مظـاهر الوجـه أو الجسم وتضـع الثـخص في حالـة صـية ونفسية مسـتقرة ـ أمـا الإجهاض فهـي عمليـة مـن المـرخص أن يقوم بهـا الطبيـب إذا كانـت ضـرورية لإنقـاذ

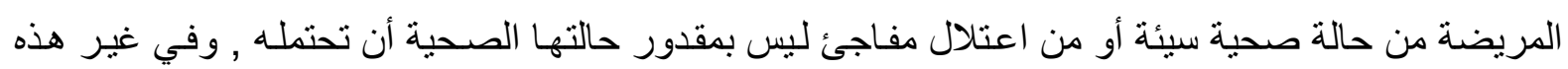
الأحو ال فأن الطبيب يكون معرضا للمسؤولية(·r) ـوقد يتصف عمل الطبيب في المر افق العامـة بالمشروعية لسبب آخر يكمن في تنفيذ القانون("rا") , أو تنفيذ أمر صادر إليه من السلطة كما يحدث في حالة تفتـي الأوبئة , 


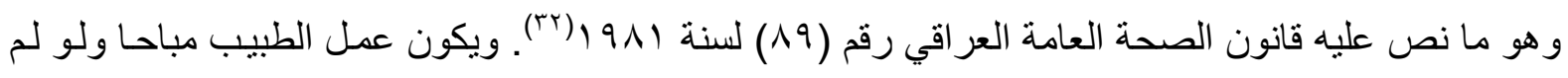
يقترن برضا المريض إذا قامت حالة عاجلة توصف بحالة الضرورة كمـا لو كان المريض في وضـع تحف بـه

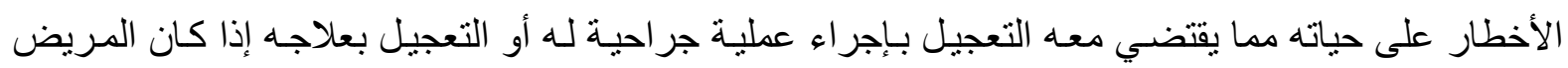

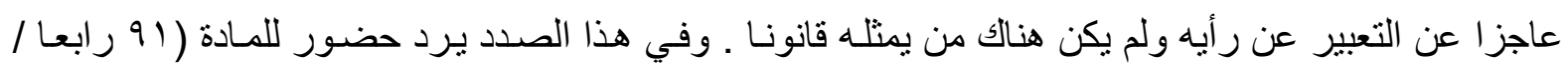
ب) من قانون الصحة العامة المذكور التي نصت على أنه : (بـ لا يجوز إجر اء عملية جراحية , إلا بموافقة

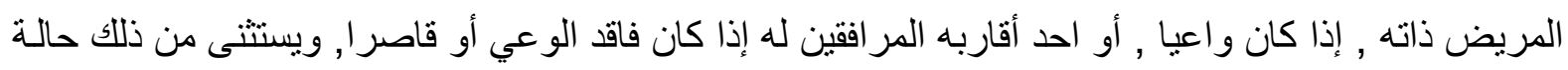
تعرض حياة المريض إلى موت أو خطر حال عند تأخر إجرائها , فيجوز عندئذ إجر اء العملية الجراحية , إنقاذا لحياة المريض , دون تحقق الموافقة المذكورة)(بَّ) . وقد أثـار قانون العقوبـات العر اقي إلى أن لا جريمـة إذا وقع الفعل استعمالا لحق مقرر بمقتضى القانون ويعتبر استعمالا للحق: (عمليات الجراحة و العلاج على أصول الفن متى أجريت برضاء المريض او ممثله الثرعي او أجريت بغير رضاه أيهما في الحالات العاجلة)(ع" ). لقد ثار إثكال في فرنسا عن مساءلة المستشفى العام عن أخطاء الطبيب باعتبار المستشفى متبوعا ، وذلك

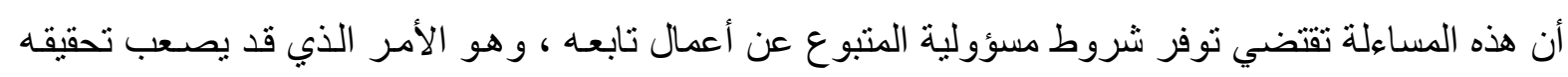

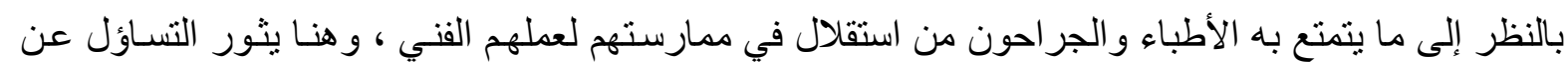
مدى توفر عنصري التوجيه والرقابة بين إدارة المستشفى والطبيب و التي يسأل بمقتضاها الأول عن خطأ الثاني ـ فقد ذهب رأي في الفقه إلى أن الاستقلال الذي يتمتع به الطبيب في ممارسة عمله يمنع تبعيته لنخص آخر إذا

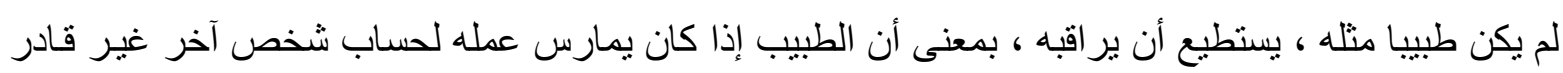

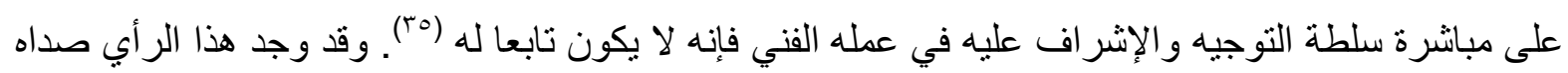

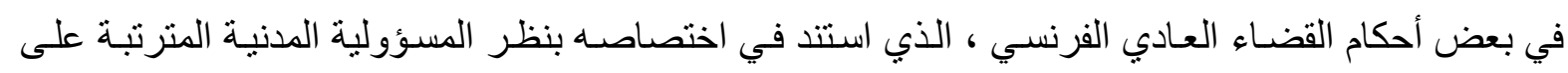
عمل الطبيب الممارس في مستشفى عام ، على أساس أن الأطباء و الجر احين بالمستشفيات العامـة ليسو اتـابعين للإدارة ، و إنما يمارسون عملهم الفني بكل استقلال ، وأن خطأهم المهني لا يرتبط بسير المرفق العام ومن ثم

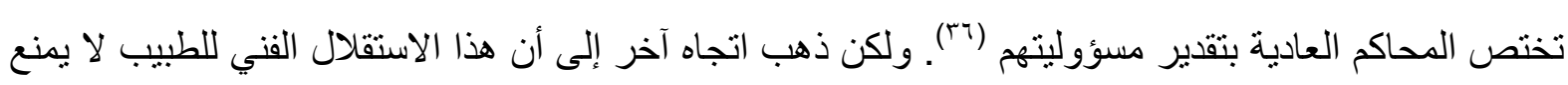
من خضو عه لرقابة إدارة المستتفى في أدائه لو اجباته بل إنها تثمل كل من يؤدي عملا لحسابها وتحت رقابتها

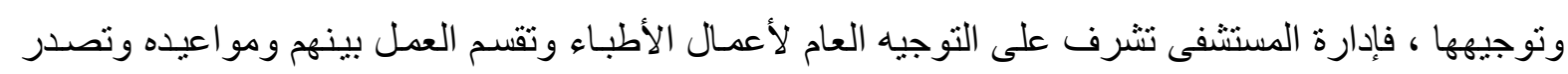

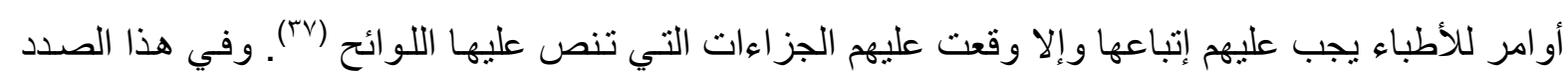
قضت محكمة باريس في // / جوليه / / بأن اختصاص القضاء الإداري بنظر المسؤولية عن أعمال الأطباء

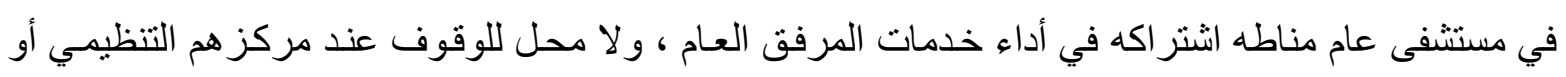

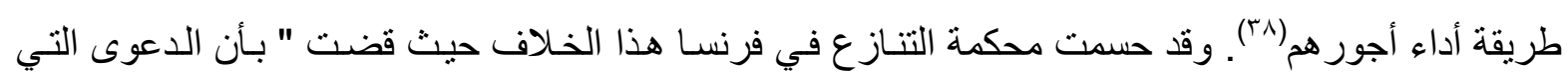
يرفعها المريض أو خلفه ضد الطبيب أو الجر اح الذي يعمل بالمستشفى العام لخطئه في أداء عمله الطبي لا

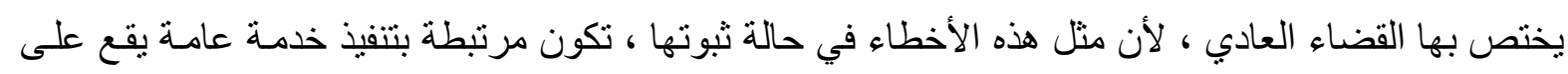

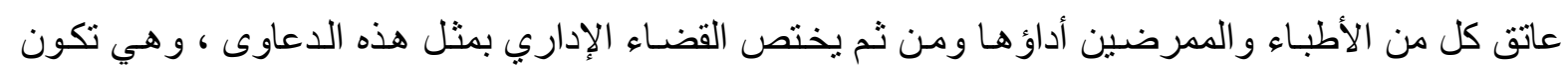


صالحة للحكم بتعويض المريض الذي لحقه الضرر، باعتبار أن الطبيب الذي يعمل في مسنشفى عام يعتبر موظفا عاما ليس بينه وبين مريضه أي عقد .

\section{المطلب الثاني- آثار المسؤولية التأديبية للعاهلين في الإدارة الصحية}

تتمثل تلك الآثار في فرض العقوبات التأدييية على العاملين في الإدارة الصحية , وكذلك في الحق في

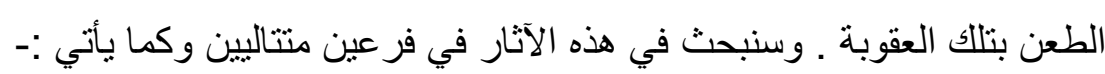

- - الفرع الأول : العقوبة التأديية .

-

الفرع الأول- العــــوبــة التـأديبـيـــة

تعرف العقوبة التأديبية بأنها : (( الجز اءات التي توقع على مرتكب الجرائم التأديبية من الموظفين ،

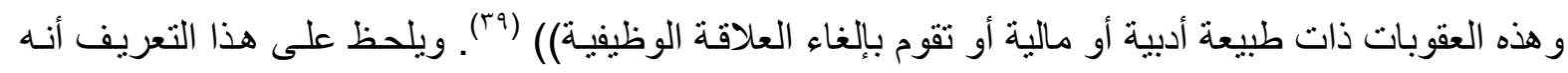

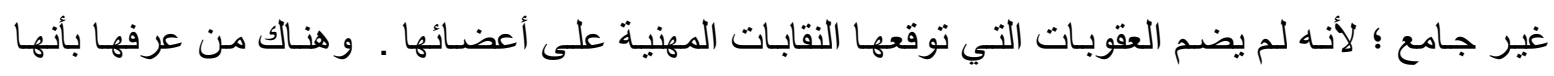

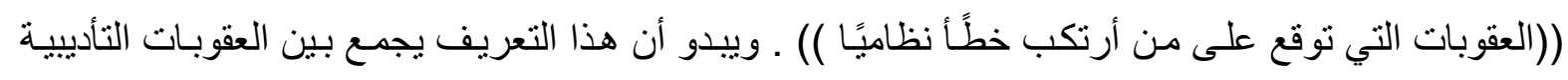

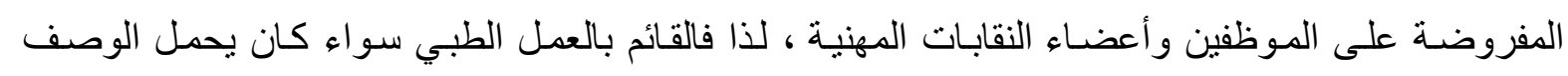
الوظيفي ، أو كان يحمل وصف عضو نقابة مهنية مرتبطة بالعمل الطبي ، إذا ارتكب الجريمـة التأدييية يكون

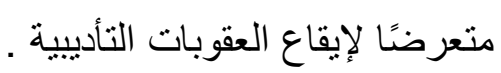

إن القاعدة العامة في القانون التأديبي تتمثل في قيام المشرع بتحديد قائمة بالعقوبات التأديبية التي يجوز توقيعها ، ويترك للسلطة التأديبية المختصة حرية اختيار العقوبة الملائمسة من بين العقوبات المقررة ، فاختيار العقوبة إذًا هو من قبيل السلطة التقديرية لجهة الإدارة ، وسلطة الإدارة في اختيار العقوبـة الملائمسة تختفي في لئي

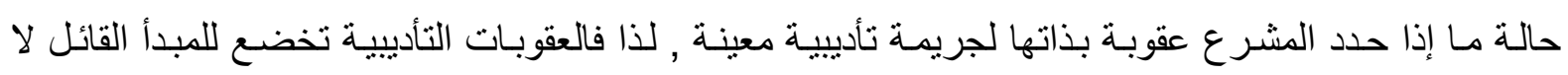

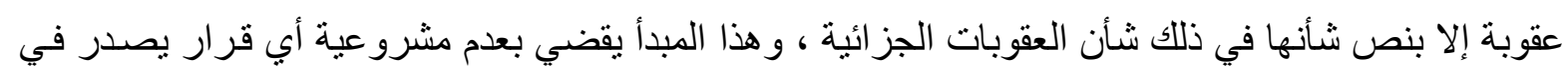
حق الموظف يكون غير عقابي في ظاهره ولكنه يخفي في طياته عقوبة تأديبية(·ء) . و هنالك العديد من المبادئ

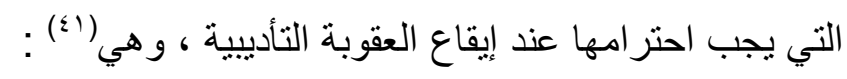

1 ـ شرعة الجزاء : يجب أن يكون من بين الجزاءات التي نص عليها القانون على سبيل الحصر ، فالسلطة

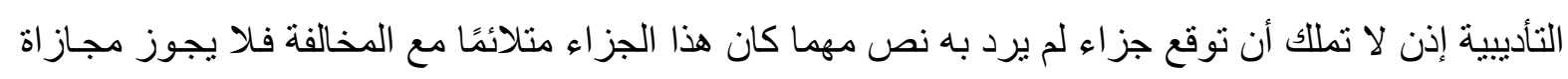

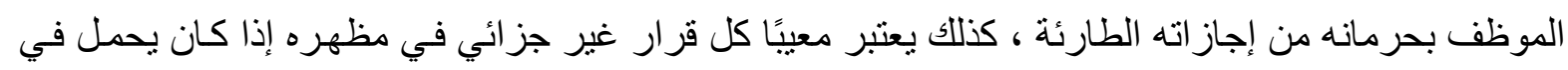
طياته عقوبة تأديبية كأن يجازى الموظف تحت ستار نقله. Y . عدم تعدد الجزاء : لا يجوز معاقبة الموظف مرتين متتاليتين عن مخالفة واحدة ، و المقصود هو عدم تعدد العقوبات التأديبية عن ذات المخالفة ، فليس هناك ما يمنع إذن أن يجازى الموظف عن ذات الفعل بعقوبة تأديبية و أخرى جنائية ، كذلك قد يجيز المشرع هذا التعدد بنص خاص ، و لا يعتبر كذلك تعددًا في الجزاء نوقيع جزاء

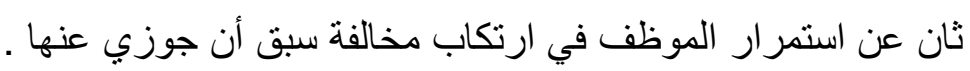


r . عدم رجعية الجزاء : إن الجزاء لا يرتب أثره إلا من تأريخ توقيعه ، ولا يجوز أن يرتد إلى تأريخ ارتكاب المخالفة مهما كانت خطورتها ، وليس ذللك إلا تطبيقًا لمبدأ عدم رجعية القرار ات الإدارية. ع .تناسب الجز اء مع المخالفة :هذا المبدأ العادل أخذ به القضاء الإداري، وفحواه أن الجزاء لا يكون مشوبًا بغلو صارخ بالنسبة إلى المخالفة المرتكبة.

إن المشرع العر اقي حدد العقوبات التأدييية لموظفي الدولة , وذلك يشمل الاطباء الموظفين العاملين في المستثفيات و المر اكز الصحية الحكومية والموظفين الفنيين و الاداريين العاملين فيها و غير هم من موظفي الدولة ، لذا سنتناول تلك العقوبات في قانون انضباط موظفي الدولة رقم ع ا لسنة (99 19 , حيث تدرج القانون المذكور في إيراد العقوبات التاديبية من الأخف إلى الأثد ، و هذه العقوبات هي (r؟گ) : ا- لفت النظر ، ويكون بإثعار الموظف تحريريًا بالمخالفة التي ارتكبها وتوجيهه لتحسين سلوكه الوظيفي ،

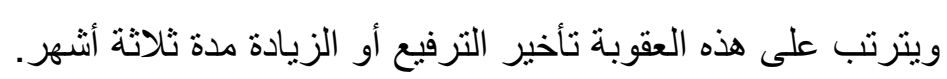

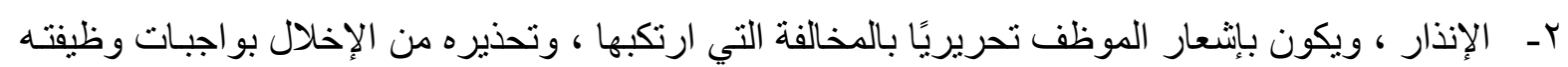

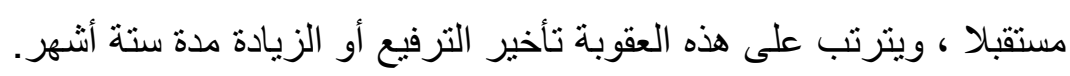
بـ - قطع الر اتب ، ويكون بحسم القسط اليومي من راتب الموظف لمدة لا تتجـاوز عشرة أيسام بـأمر تحريري تذكر فيه المخالفة التي ارتكبها الموظف واستوجبت فرض العقوبة ويترتب عليها تأخير الترفيع أو الزيـادة لمدة خمسة أثنهر في حالة قطع الراتب لمدة لا تتجاوز خمسة أيام ، وشهر واحد عن كل يوم من أيام قطع الراتب في حالة تجاوز العقوبة مدة خمسة ايام . عـ - التوبيخ ، ويكون بإثعار الموظف تحريريًا بالمخالفة التي ارتكبها و الأسباب التي جعلت سلوكه غير مرض

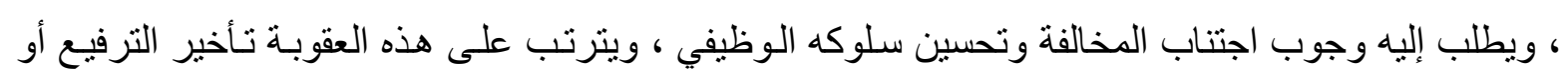
الزيادة مدة سنة واحدة .

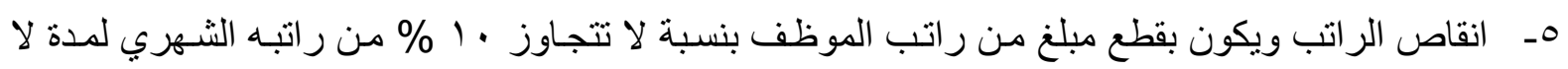
تقل عن ستة أشهر و لا تزيد على سنتين ، وينم ذلك بأمر تحريري يشعر الموظف بالفعل الذي ارتكبه ، ويترتب على هذه العقوبة تأخير الترفيع أو الزيادة مدة سنتين. ج- تنزيل الدرجة ، ويكون بأمر تحريري يشعر فيه الموظف بالفعل الذي ارتكبه ويترتب على هذئ هذه العقوبـة ، تنزيل راتب الموظف إلى الحد الأدنى للارجة التي دون درجته مع منحه العلاوات التي نالها في الدرجة المنزل

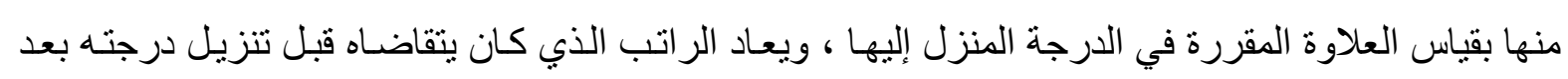

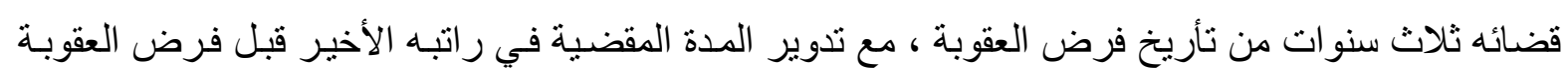
بالنسبة للموظف الخاضع لقو انين أو أنظمة أو قو اعد أو تعليمات خدمة تأخذ بنظام الدرجات المالية و الترفيع ، أما بالنسبة للموظف الخاضع لقو انين أو أنظمة أو قو اعد أو تعليمات خدمة تأخذ بنظام الزيادة كل سنتين ، فيتن تخفيض زيادتين من راتب الموظف ويعاد إلى الراتب الذي يتقاضاه قبل تتزيل درجته بعد قضائه ثنات سنوات

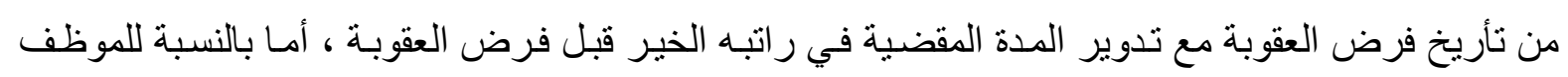


الخاضع لقو انين أو أنظمة أو قو اعد أو تعليمـات خدمـة تأخذ بنظـام الزيـادة السنوية فيتم تخفيض ثنلاث زيادات سنوية من راتب الموظف مع تدوير المدة المقضية في راتبه الأخير قبل فرض العقوبة.

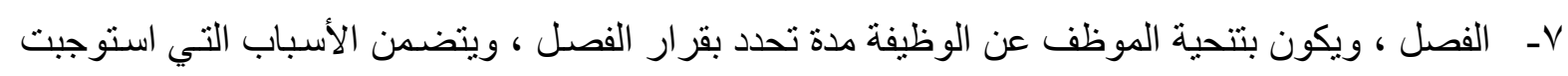

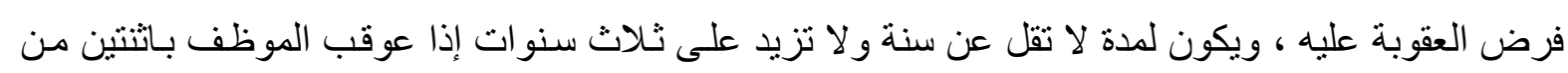
العقوبات أو بإحدا ها لمرتين وارتكب في المرة الثالثة خلال خمس سنوات من تأريخ فرض العقوبة الأنس الأولى فعلا

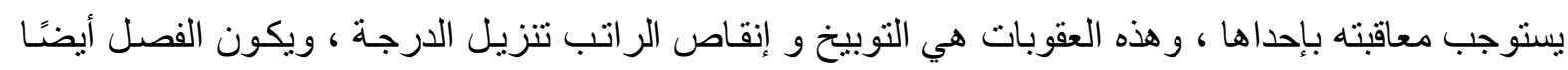

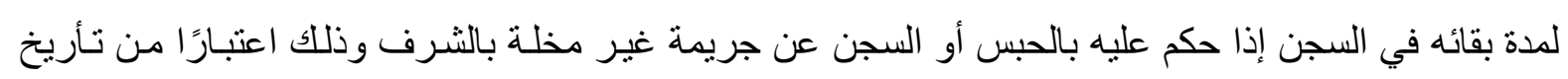

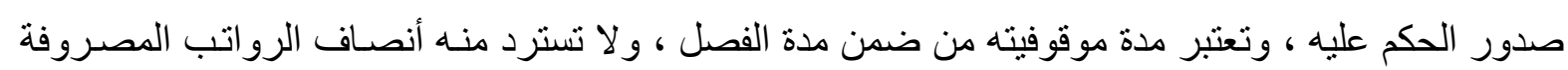
له خلال مدة سحب البد.

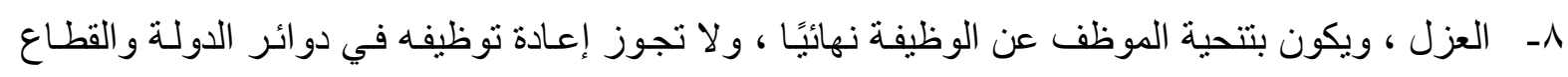
العام وذلك بقر ار مسبب من الوزير في حالة ما إذا ثبت ارتكابه فعلا خطيرًا يجعل بقائه في خدمة الدولة مضـرًا

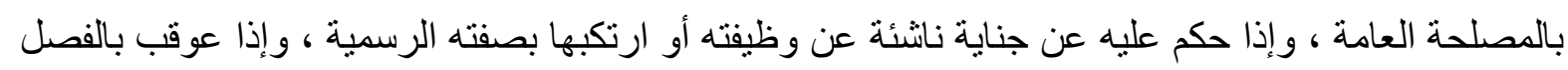
ثم أعيد توظيفه فارتكب فعلا يستوجب الفصل مرة أخرى. وقد لا تتناسب العقوبات التأدييية المنصوص عليها في قانون انضباط موظفي الدولة ، مع بعض الجرائم التي يرتكبها بعض الموظفين المهنيين ، لذا اصدر مجلس

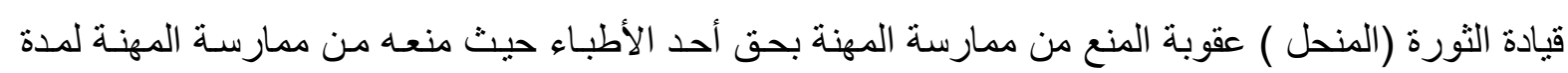
سنتين , وقد يكون المنع مطلقًا (ب؟).

أما في مصر فقد جاء قانون نظام العاملين المدنيين في الدولة ، وبين العقوبات التأديبية وهي(؟؛) :

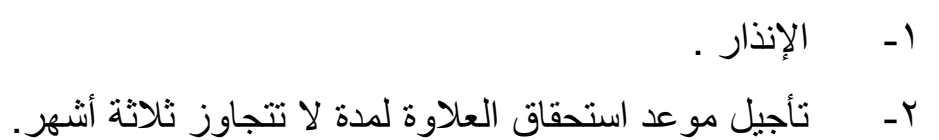

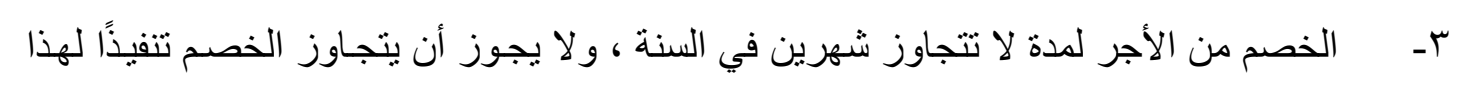

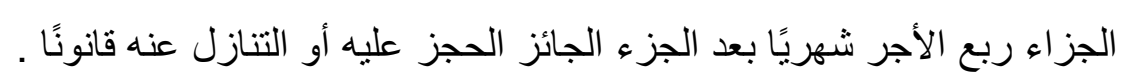

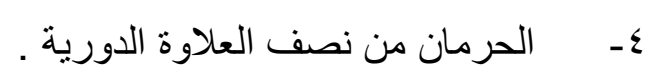

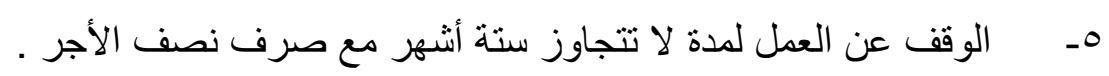

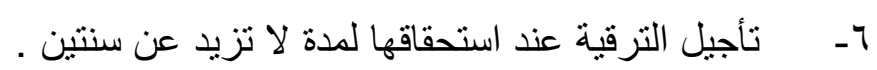

$$
\text { N- - م }
$$

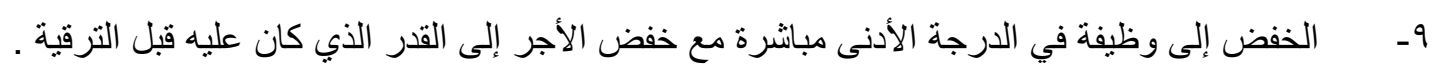

$$
\text { • 1 ا - الإحالة إلى المعاش . }
$$

أما بالنسبة للعاملين من شاغلي الوظائف العليا فلا توقع عليهم إلا عقوبة التنبيه ، أو اللوم ، أو الإحالة

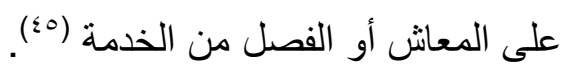




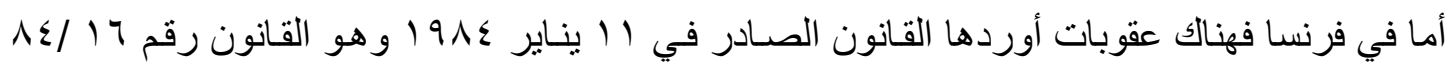

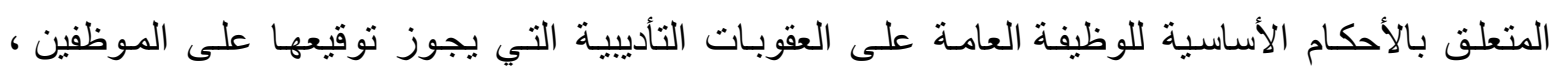

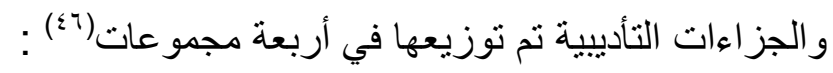

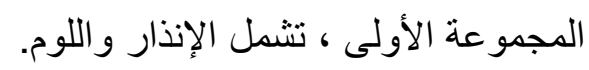

المجموعة الثانية ، تثمل الحرمان من الترقية وخفض الدرجة والخصم من المرتب مدة لا تزيد عن 1 يومًا. المجموعة الثالثة ، وتشمل الاستبعاد من الوظيفة لمدة ثلاثة شهور في خلال سنتين، وتنزيل الدرجة. المجمو عة الرابعة ، وتشمل الإحالة إلى المعاش ، و العزل.

وفي ضوء التشريعات التي تم ذكر ها ، يتبين بأن العقوبات التأديبية ، تتقسم إلى(؟`):

أو لا : عقوبات معنوية ، ويقصد بها إظهار عدم رضا الإدارة عن فعل الموظف أو العامل وتحذيره من العودة

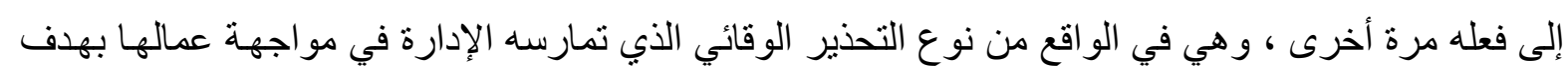
وقايتهم ومنعهم من العودة إلى ارتكاب أخطاء جديدة مستقبلا.

ثانيًا : العقوبات المالية ، وهذه العقوبات تتصب بصورة مباثرة على المرتب الذي يتقاضساه الموظف أو العامل بصفة دورية ومنتظمة بسبب قيامه بأداء أعمال وظيفته(يُء). ثالثًا : العقوبات التي تنهي رابطة التوظف او العمل ، وتعد من أغلظ العقوبات وأبلغها خطورة لما يترتب عليها

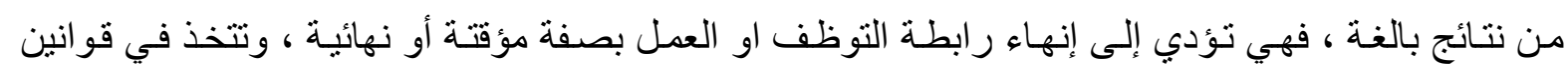
التوظف عدة صور و هي الوقف عن العمل ، و الإحالة على التقاعد ، والعزل عن الوظيفة(9؛ ).

\section{الفرع الثاني- هق الطمن في العقوبة التأديبية}

يعد الطعن من الضمانات التي وضعها المشرع لكي يضمن تحقق العدالة في القرار التأديبي ، لذا سنبحث فيما يأتي آلية الطعن في العقوبـة التأديبية . حيث نظم قانون انضباط موظفي الدولـة طريقة الطعن في قرار العقوبة التأديبية وللعقوبات الواردة فيه جميعها, بعد ان كانت العقوبات التي يفرضها الوزير او رئيس الدائرة او

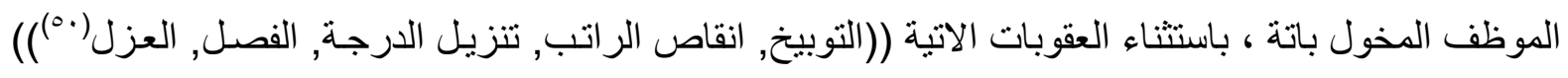

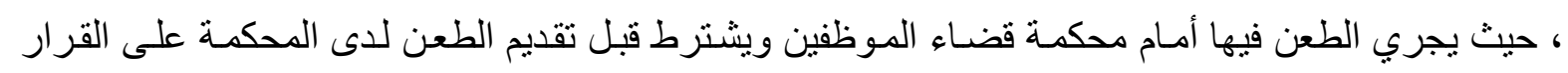
الصادر بفرض العقوبة أن يتظلم من القرار لدى الجهة التي أصدرته ، وذللك خلال ثلاثين يومًا من تأريخ تبليغ الموظف بالقر ار، ويتوجب على الجهة التي أصدرت القرار أن تبت في التظلم خـلال ثلاثين يومًا من تأريخ تقديمه ، و عند عدم البت فيه بالر غم من انتهاء هذه المدة فإن هذا الامتناع يعتبر رفضا للنظلم ـ ومن ثم ينبغي أن يقدم الطعن لاى المجلس خلال ثناثين يومًا من تأريخ رفض التظلم حقيقة أو حكمًا ولمحكمة قضاء الموظفين أن

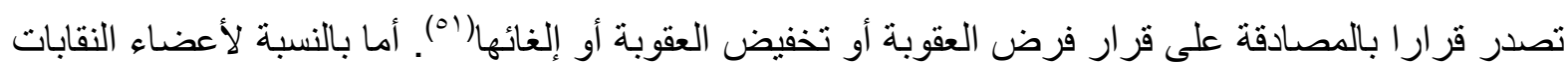

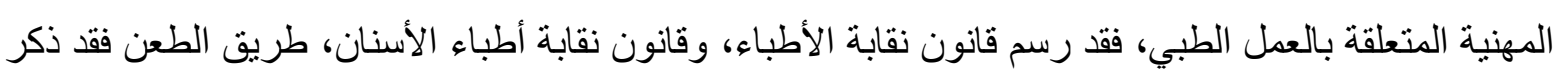


بقوله (( للوزير و النقيب و لأطر اف القضية الطعن في قرار ات لجنة الانضباط لاى مجلس الانضباط العام خلال

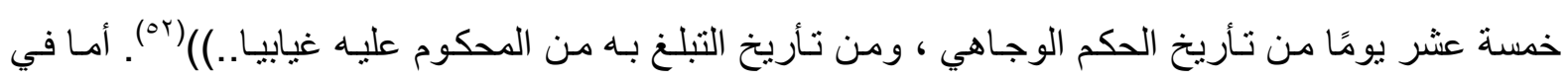

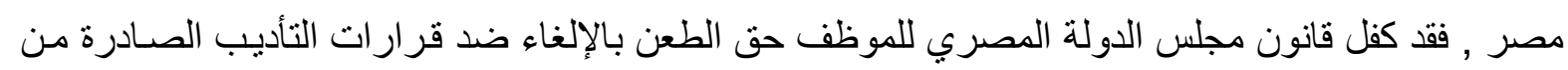

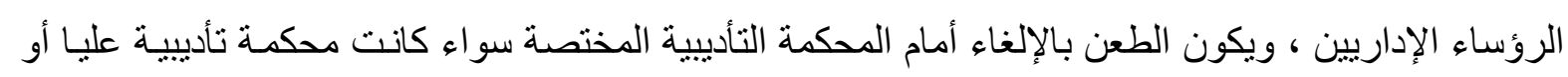
محكمة تأديب عادية حسب الفئة الوظيفية ، ويشترط قانون مجلس الدولة التظلم من القرار أمسام الإدارة مصدرة

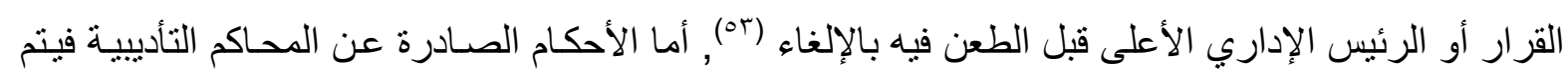

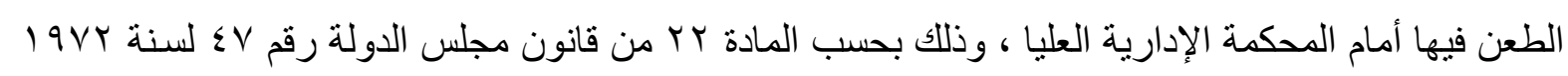

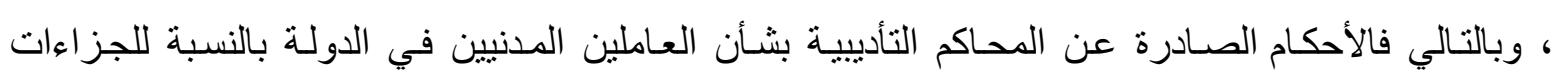

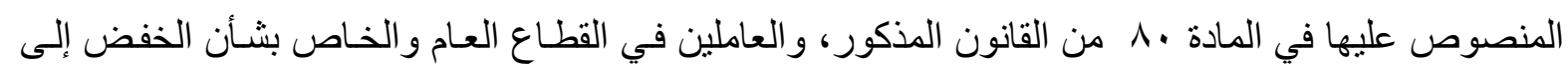
وظيفة في الدرجة الأدنى مع خفض الأجر بما لا يتجاوز القدر الذي كان عليه قبل الترقية والإحالة على المعاش ون و الفصل من الخدمة، والأحكام التأدييية بمد مدة وقف الموظف عن العمل وبصرف أو عدم صدرف جزء من

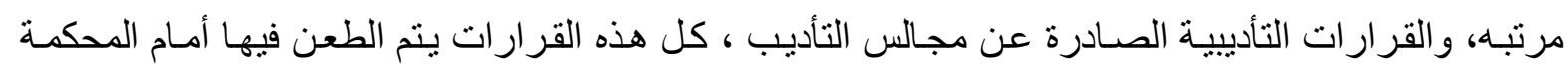

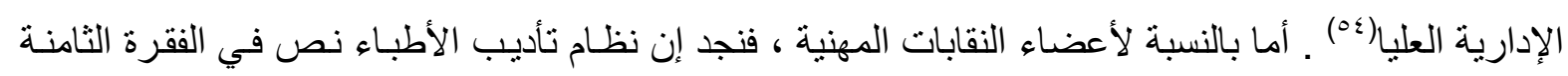
على استئناف قرارات هيئة التأديب المشكلة في نقابة الأطباء أمام هيئة تأديب استئنافية من إحدى دو ائر محكمـة فئة

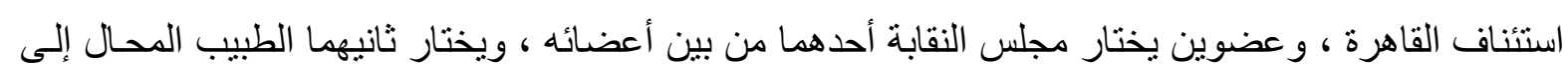
المحاكمة التأدييية من بين الأطباء (00). أما في فرنسا , فيعد مجلس الدولة الفرنسي من حيث المبدأ محكمة تمييز

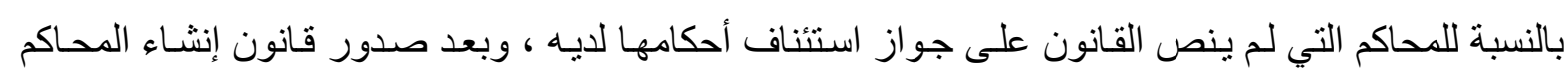
الإدارية الاستئنافية أضيف إلى الاختصاص التمييزي لمجلس الدولة الاختصـاص بنظر الطعون التمييزيـة في

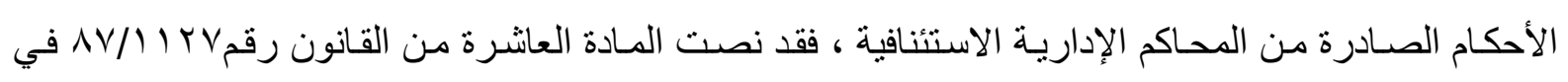

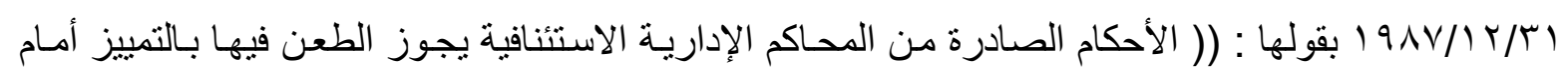
مجلس الدولة )) , لذا فإن الطعن في أحكام المحكمة الإدارية يتم بطريقتين هما : الاستئناف و التمييز ـ أمـا فيما يخص أعضـاء نقابـة الجر احين و أطباء الأسنان ، فإن القرار ات الصـادرة من المجلس الإقليمي للنقابـة يتم استئنافها أمام المجلس التاديبي القومي لنقابة الجر احين و أطباء الأسنان ، ومن ثم يتم تمبيز ها أمام مجلس الدولـة الألة الفرنسي(07)

الخاتمة

بعد ان انتهينـا مـن البحث في موضـوع ((المسؤولية التأديبيـة للعـاملين في الإدارة الصـحية)) وجدنا ان المشرع العر اقي قد وضـع تنظيما قانونيا لتلك المسؤولية , مقتفيا في ذلك اثر المشـرعين في فرنسـا ومصر. وكانت محصلة البحث في الموضوع الآنف الذكر الخروج بالعديد من الاستتناجات البعض منها يرتبط بصلة

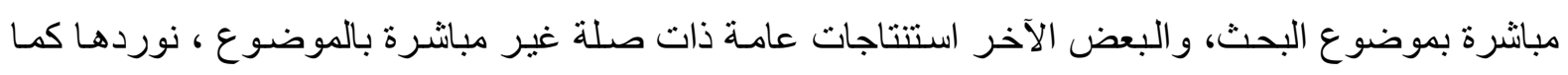


1- - إن المسؤولية التأديبية التي تترتب على العمل الطبي تنجم عن الإخـلال بواجبـات الوظيفة ، وهي مسؤولية مرتبطة بالمرفق الصحي العام ، الذي يخضع للقانون العام وان الطبيب الذي يعمل في المستشفيات

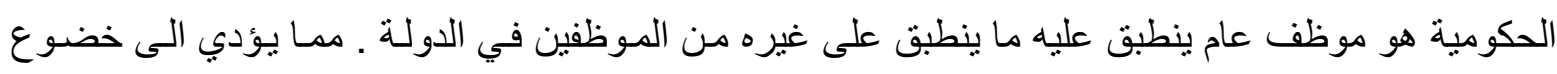

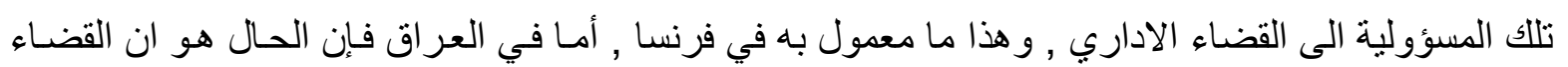

العادي هو من يتولى الفصل في الدعاوى المقامة على المر افق العامة الصحية و على الأطباء العاملين فيها .

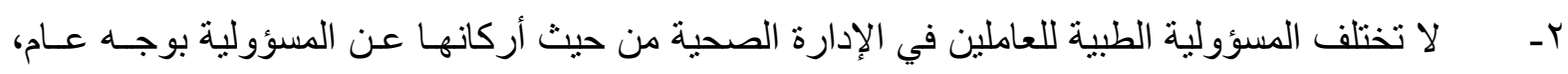

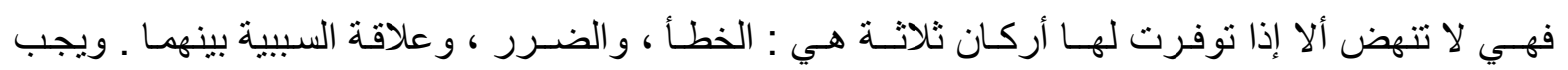
على مدعي الضرر إثبات أركان المسؤولية بما فيها العلاقة السببية التي بمكن إثباتها بجميع طر ائق الإثبات بما فيها القرائن القضائية . بـ - أختلف الر أي الفقهي حول الأساس الذي يقوم عليهه حق الطبيب في إجراء العلاج أو الجراحة , و هي أفعال تمس أبدان الناس وقد ينجم عنها أحيانا موت إنسان ـ فهناك رأي يرى أصحابه أن أساس الحق هو انتفاء

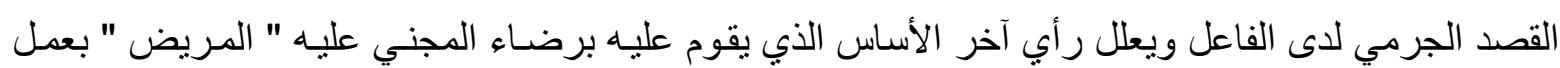
الطبيب , ويسنده رأي ثالث - وهو ما نميل إليه - إلى القانون كونه هو الذي أباح أفعال الطبيب . ع-إن القاعدة العامة في القانون التأديبي تتمثل في قيام المشرع بتحديد قائمة بالعقوبات التأدييية التي يجوز توقيعها ، ويترك للسلطة التأدييية المختصة حرية اختيار العقوبة الملائمة من بين العقوبات المقررة ، فاختيار

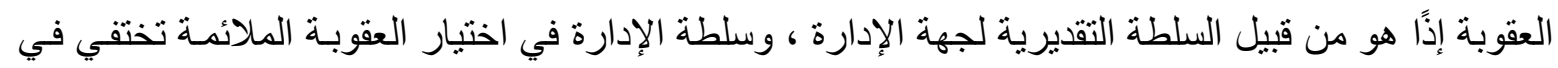

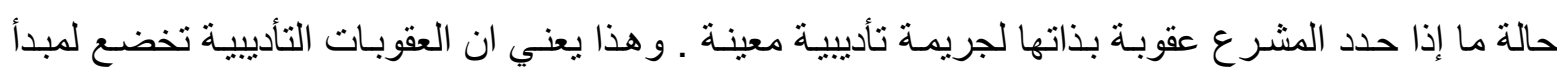
المشروعية . ولكن هذا الخضوع ليس خضو عا كاملا , حيث ان مبدأ المشرو عية يقضي بـأن لا جريمـة و لا عقوبـة إلا بنص , أمـا في العقوبـات التأدييية فإن العقوبـات فقط هي المحددة بـالنص أمـا الجرائم التأديبية فقد تركها المشرع لتقدير الإدارة .

๑ـ يعد الطعن من الضمانات التي وضـعها المشر ع لكي يضمن تحقق العدالة في القرار التـأديبي ، حيث نظم قانون انضباط موظفي الدولة طريقة الطعن في قرار العقوبة التأديبية وللعقوبات الواردة فيه جميعها .

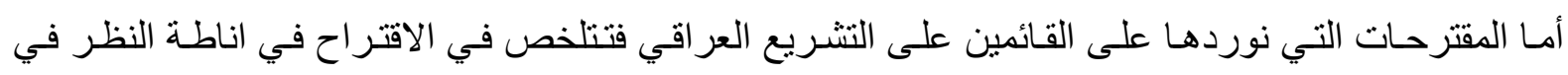

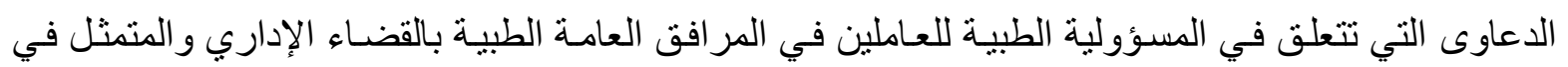

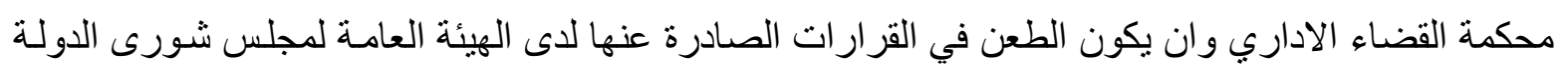

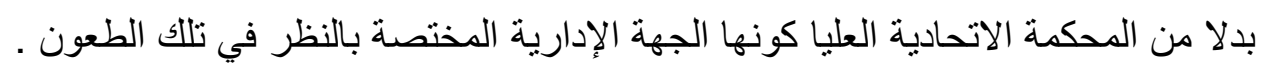

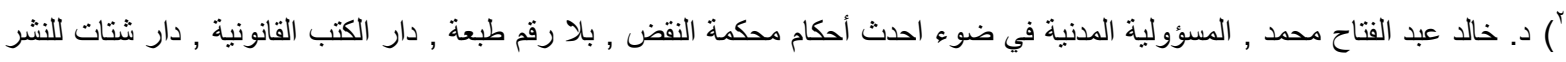

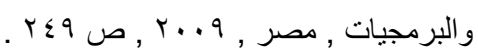


؟) د. عبد الحكم فوده , الخطأ في نطاق المسؤولية التقصبرية , دار الألفي لتوزيع الكتب القانونية , الإسكندرية , 1990, ص الع, نقلا عن رواء

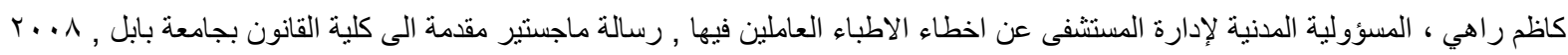
. VT ص , מ

؛) د. منذر الفضل , التجربة الطبية على الجسم البشري ومدى الحماية التي يكفلها القانون المدني والقوانين العقابية الطبية , بحث منشور في

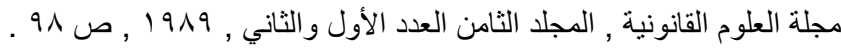

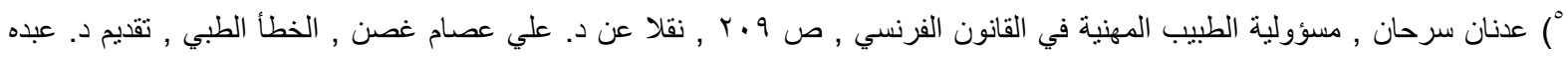

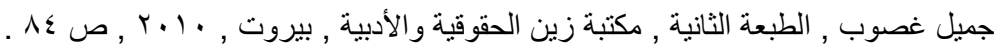

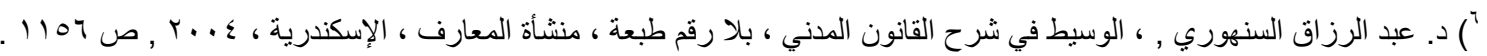

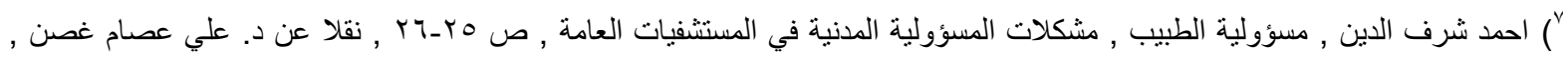
المصدر السابق , ص 10 .

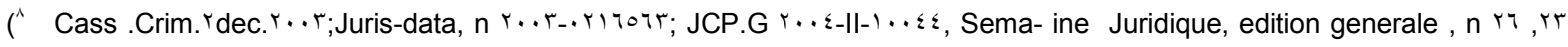
juin $r$.. ¿. P. $11 \wedge 1$, Patrick MISTRETTA

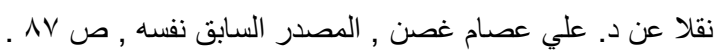

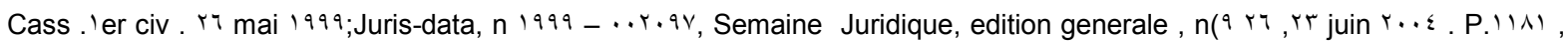
Patrick MISTRETTA

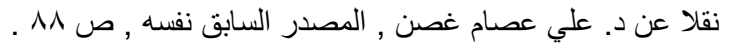

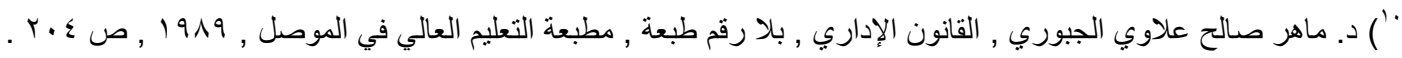

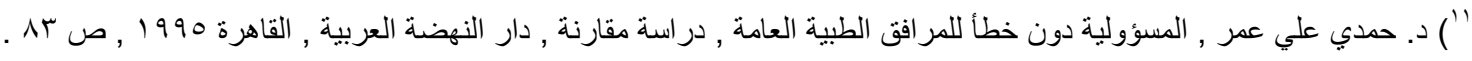

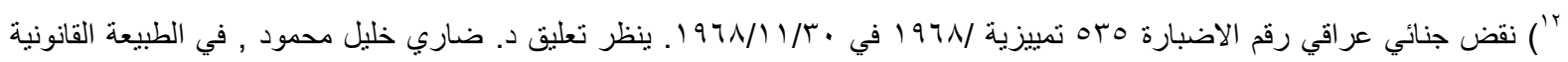

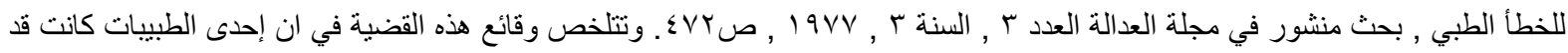

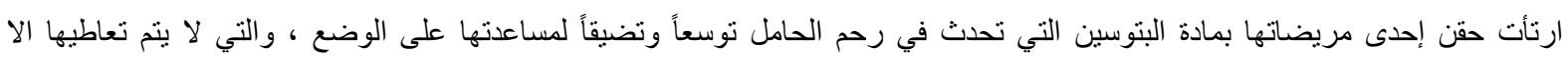

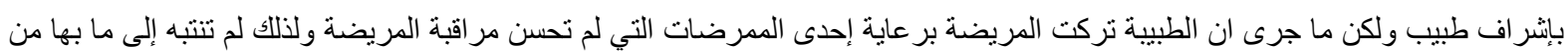
انخفاض في ضغط الدم أدى إلى وفاتها .

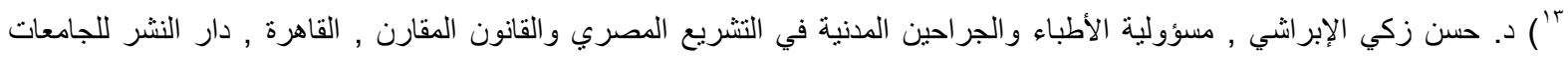

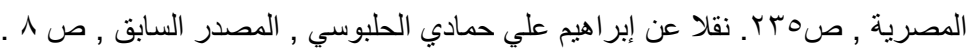

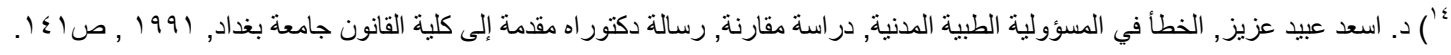

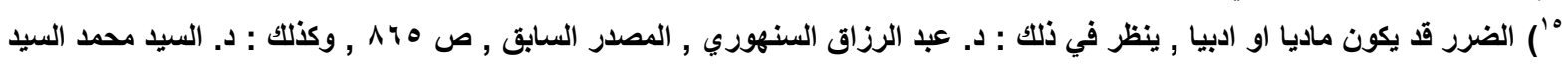

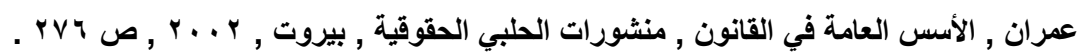

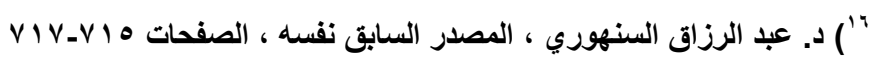
Vال) ينظر د. ابر اهيم احمد محمد الرواشدة , المسؤولية المدنبة لطبيب التخدير دراسة مقارنة , بلا رقم طبعة , دار الكتب القانونية , دار شتات

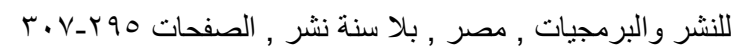

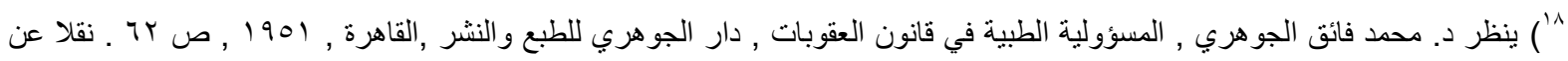
د. نجيب خلف احمد , مسؤولية المستشفى العام عن اخطاء اطبائه , بحث منشور في مجلة العلوم القانونية , كلية القانون جامعة بغداد , العدد

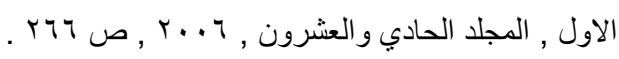
9' الحمد حسن الحياري , المسؤولية المدنية للطبيب في ضوء النّاد النظام القانوني الاردني والنظام القانوني الجزائري , الطبعة الاولى ـ الاصدار

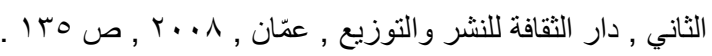

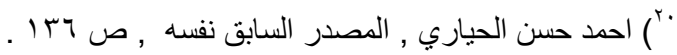

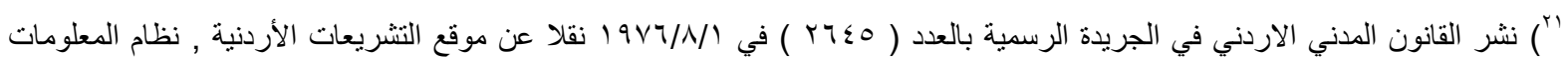
http://www.lob.gov.jo/ui/laws/search no.jsp?no=气r\&year=19V7 الوطني على الانترنت :

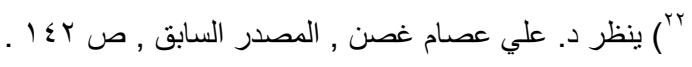




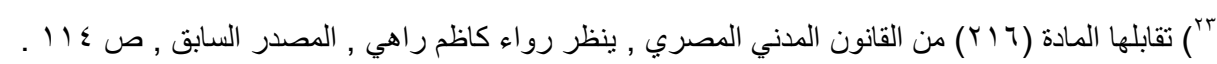

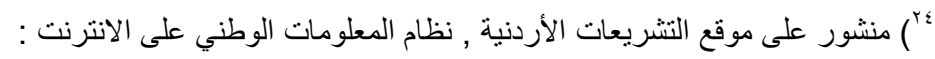

http://www.lob.gov.jo/ui/laws/search no.jsp?no= = r \&year=19v

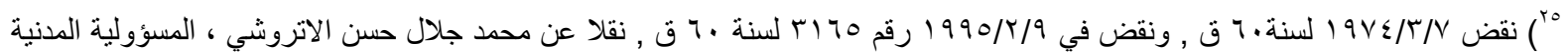

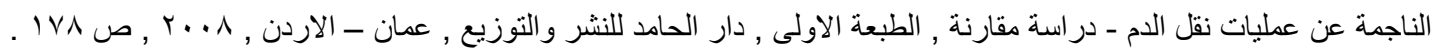

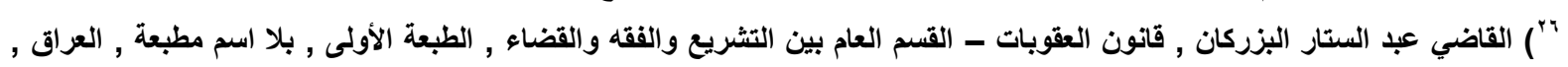

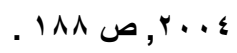

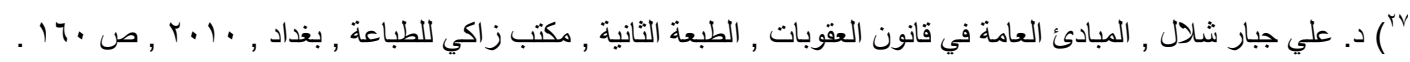

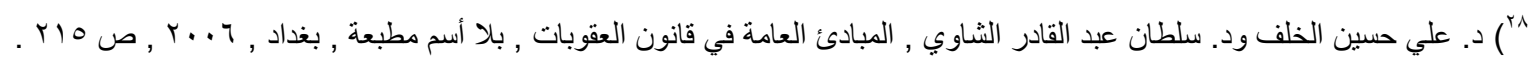

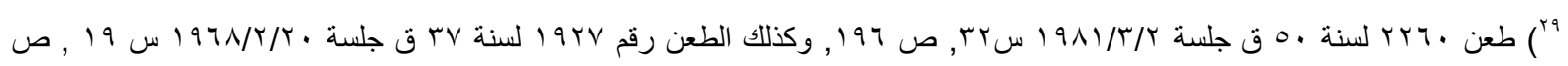

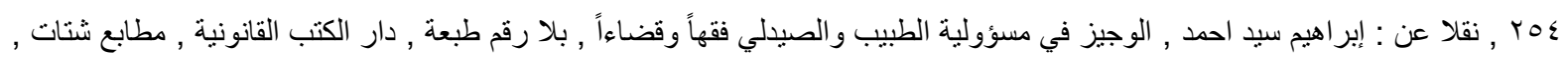

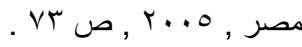
.

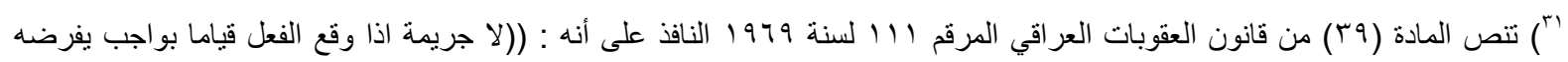

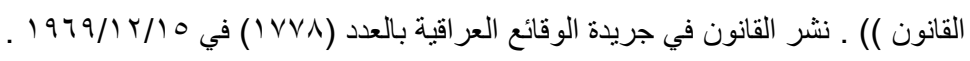

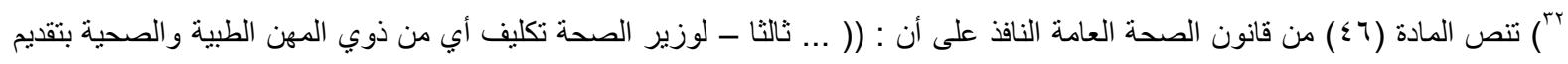
الخدمات الطبية للمواطنين عند حدوث الأوبئة وفي حالات الطوارئ وللمدد التي تنطلبها تلك الحون ادث والحاتلات ) ) ) ـ نشر القانون في جريدة

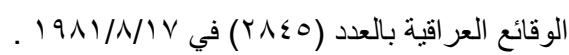

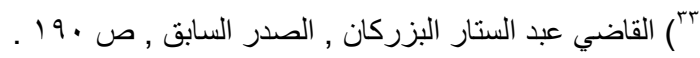

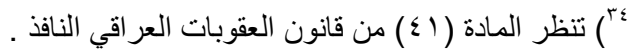

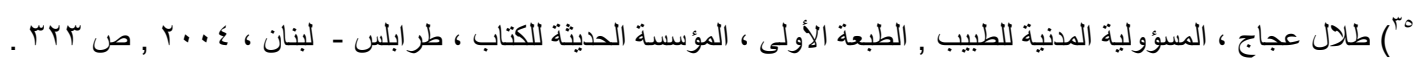

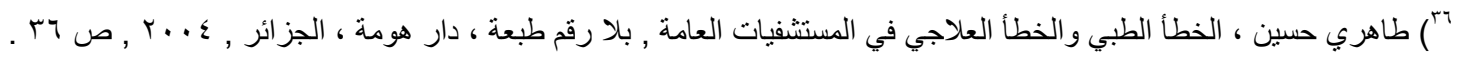

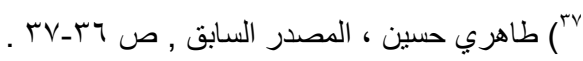

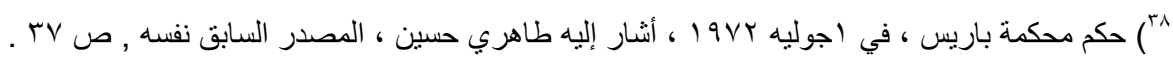

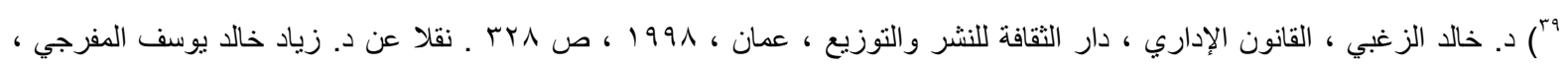

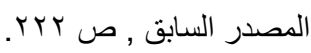

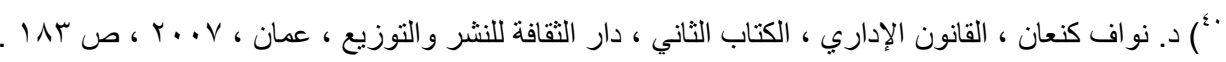

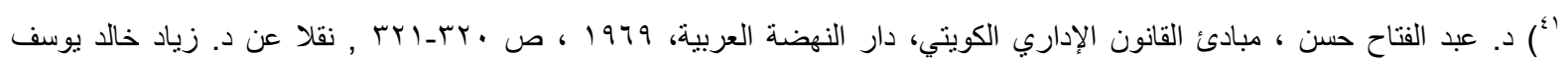

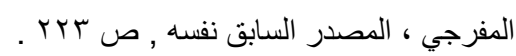

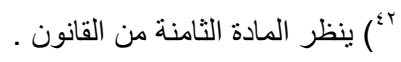

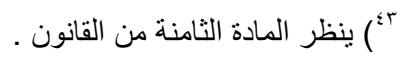

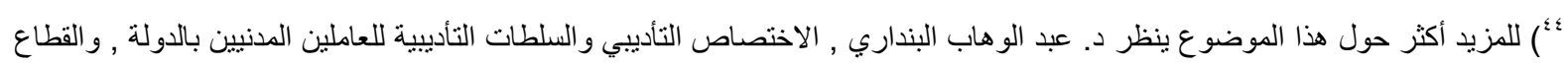

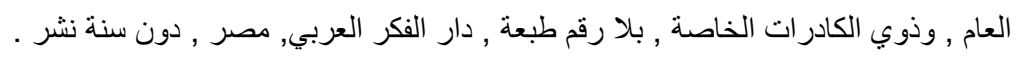

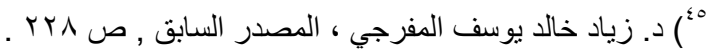

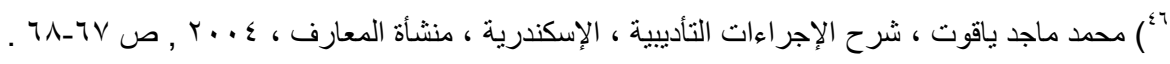

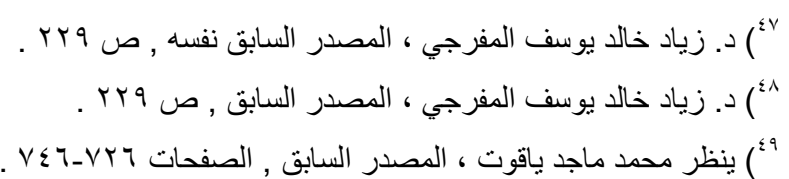




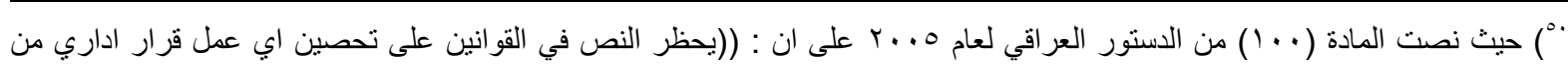

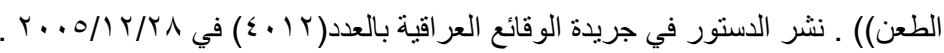

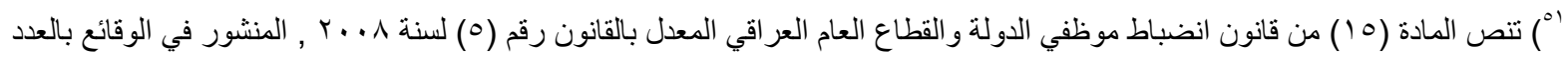

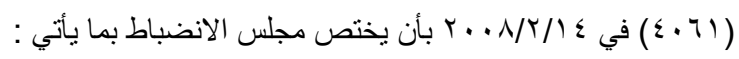

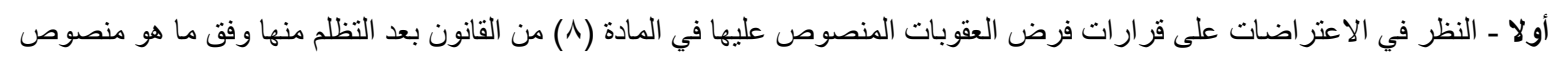

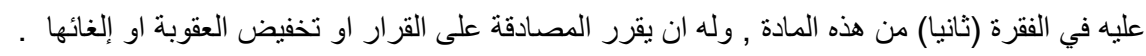

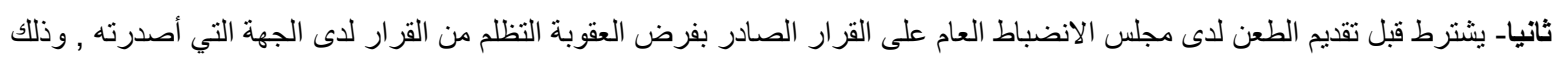

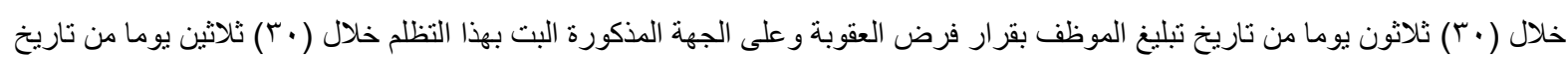

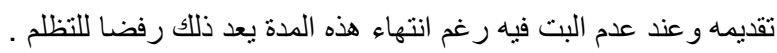
ثالثا- يشترط ان يقدم الطعن لاى مجلس الانضباط العام خلال (• ب) يوما من تاريخ تبليخ الموظف برفض التظلم حقيقة او حكما .

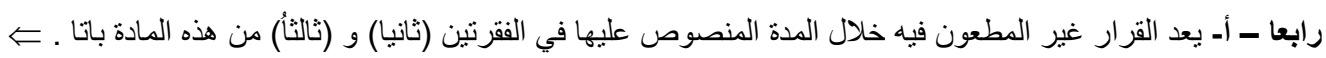

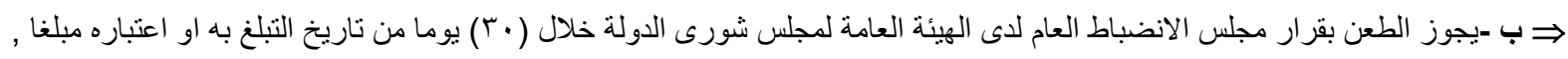
ويكون قرار الهيئة العامة الصادر نتيجة الطعن باتا وملزما . خامسا - ير اعي مجلس الانضباط العام عند النظر في الطعن أحكام قانون أصول المحاكمات الجزائية وبما يتلاءم وأحكام هذا القانون وتكون جلساته سرية .

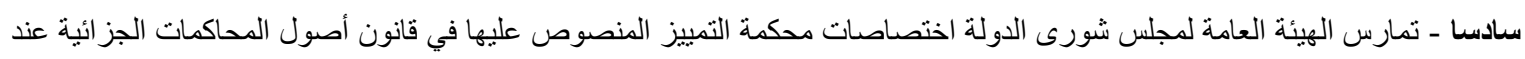
النظر في الطعن المقدم في قرارات مجلس الانضباط العام وبما يتلاءم وأحكام هذا القانون .

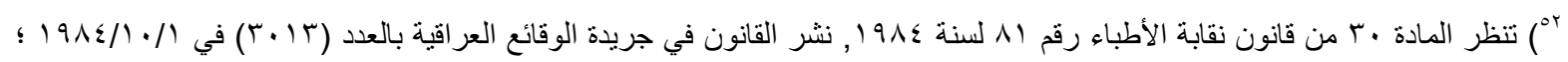

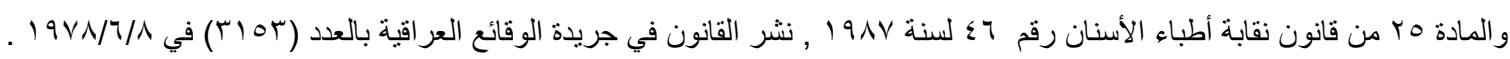

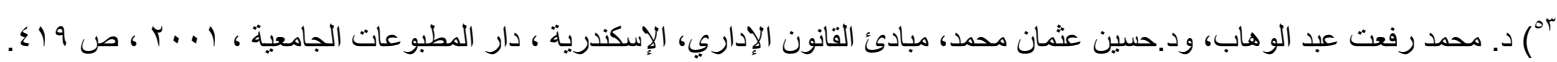

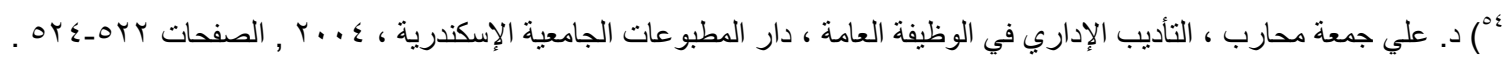

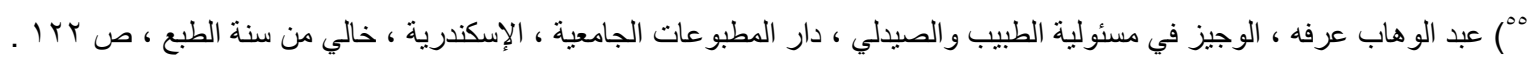

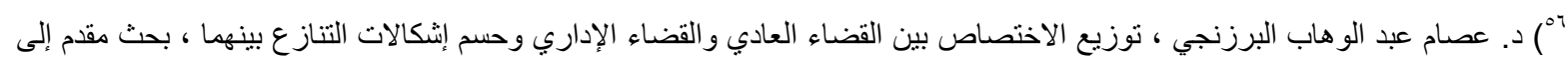

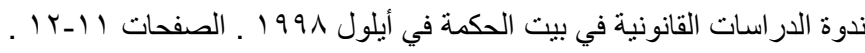

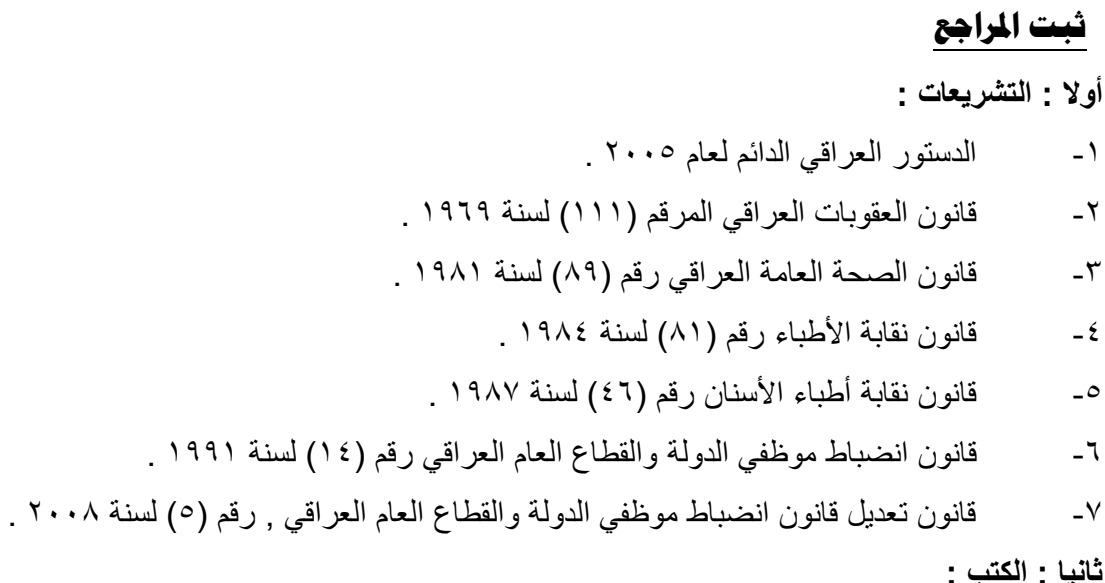

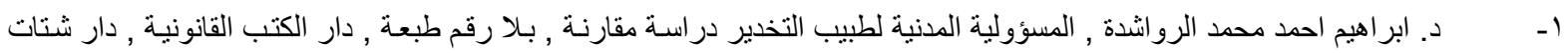

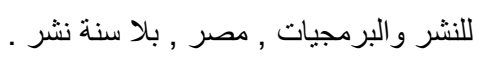

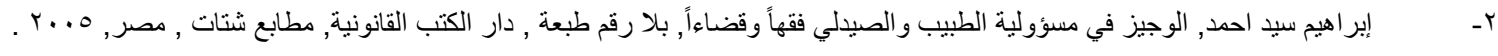

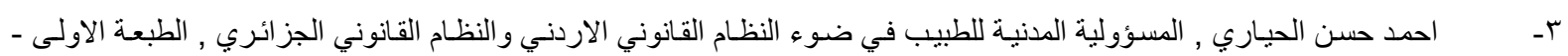

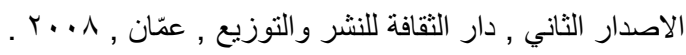

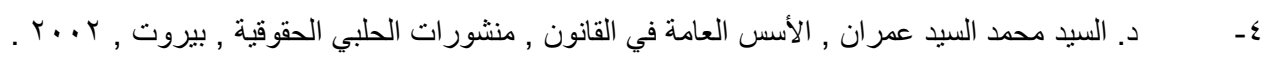


هـ د. حمدي علي عمر المسؤولية دون خطأ للمر افق الطبية العامة, دراسة مقارنة, دار النهضة العربية , القاهرة , 1990 ـ.

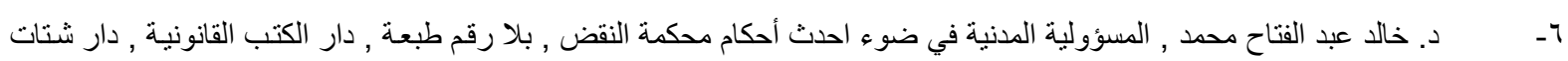
للنشر و البرمجيات , مصر , و.

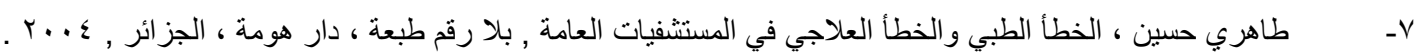

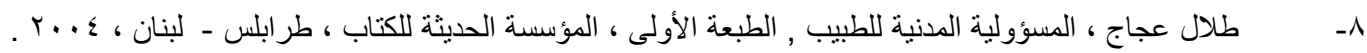

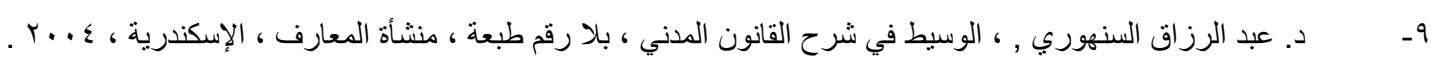

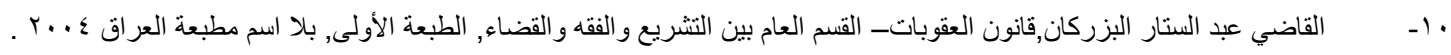

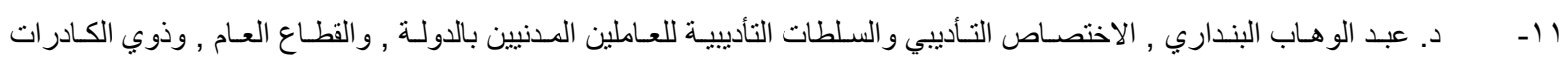

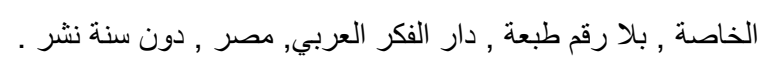

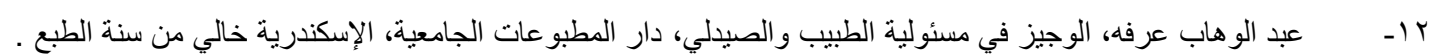

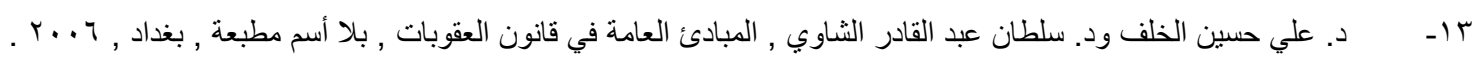

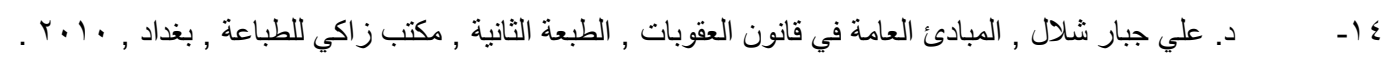

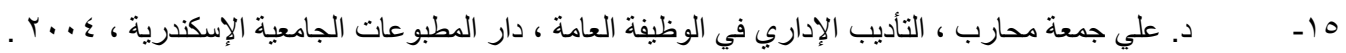

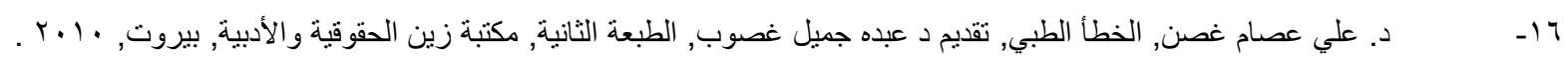

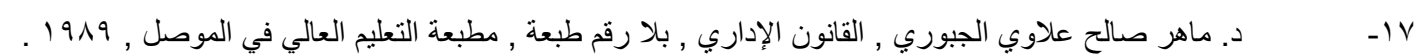

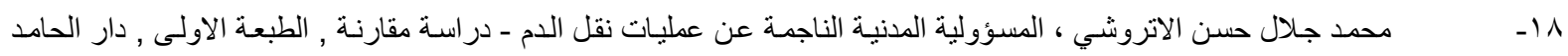

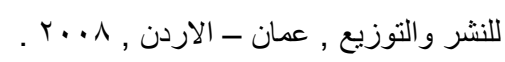

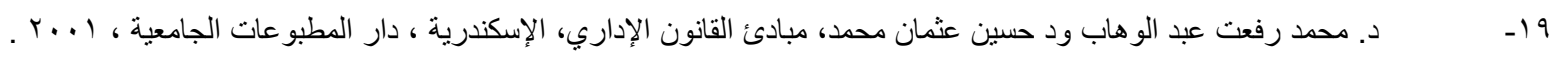

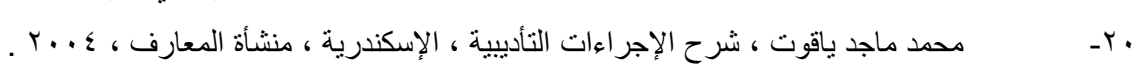

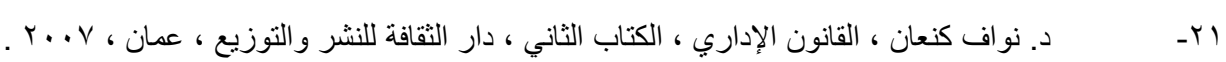

ثالثا : الاطاريح والرسائل الجامعية : ا - إبر اهيم علي حمادي الحلبوسي , الخطأ المهني و الخطأ العادي في إطلار المسؤولية الطبية , رسـالة ماجستير مقدمة الى كلية القانون

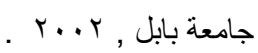

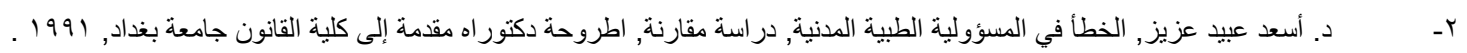

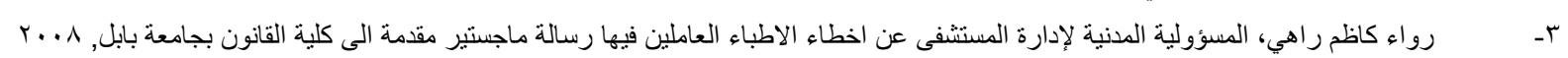

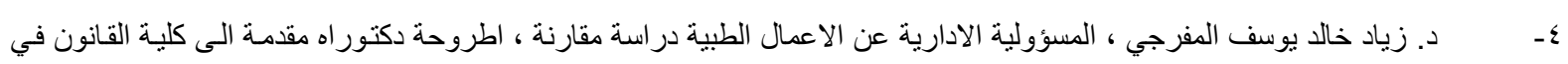

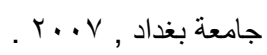

رابعا : البحوث المنشورة في المجلات العلمية :

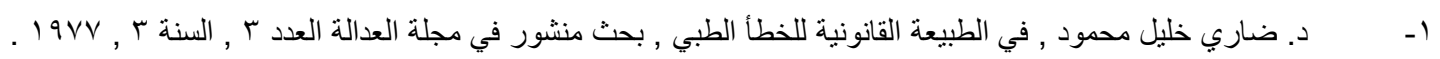

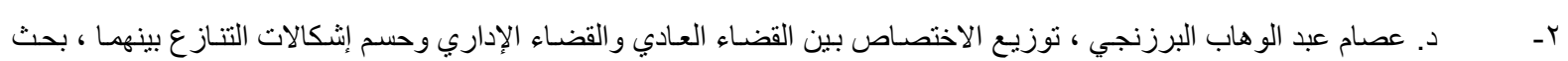

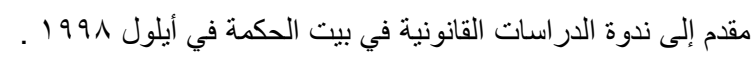

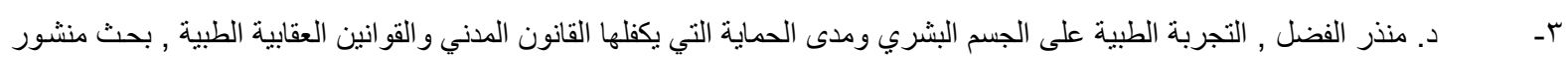

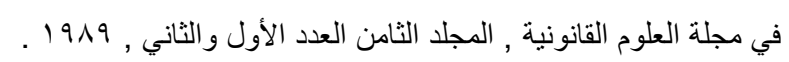
عـ - د. ديب خلف احمد , مسؤولية المستشفى العام عن اخطاء اطبائه , بحث منشور في مجلة العلوم القانونية , كلية القانون جامعة بغداد

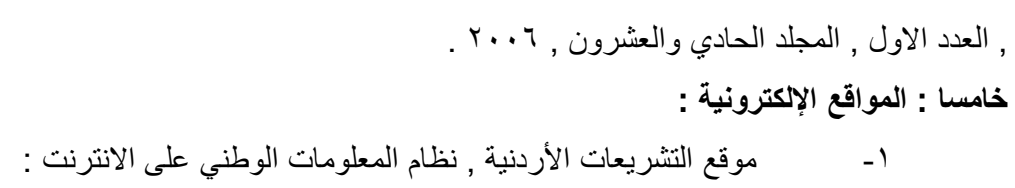

http://www.lob.gov.jo/ui/laws/search no.jsp?no= = r \&year=19v 